\title{
Targeting of synaptotagmin to neurite terminals in neuronally differentiated PC12 cells
}

\author{
Peter A. Krasnov and Grigori Enikolopov* \\ Cold Spring Harbor Laboratory, Cold Spring Harbor, NY11724, USA \\ *Author for correspondence (e-mail: enik@cshl.org) \\ Accepted 9 February; published on WWW 21 March 2000
}

\section{SUMMARY}

We have investigated structural elements that determine the accumulation of synaptotagmin, a major synaptic vesicle protein, in neurite terminals of neuronally differentiated neuroendocrine pheochromocytoma PC12 cells. We performed extensive deletion and point mutagenesis of rat synaptotagmin II, expressed mutant proteins in PC12 cells differentiated by nerve growth factor (NGF) and monitored their intracellular distribution by immunofluorescence. We found a structural element located at the carboxy-terminal domain of the synaptotagmin molecule, which is necessary for its accumulation at the terminal. Using alanine-scanning mutagenesis, we have identified two amino acids in this

\section{INTRODUCTION}

Transmission of signals at chemical synapses is accomplished by regulated release of neurotransmitters from secretory vesicles that have accumulated near the presynaptic membrane of the axon terminal. There are three main types of secretory vesicles, which carry different classes of neurotransmitters and are represented in different proportions in diverse types of neurons and neuroendocrine cells. Synaptic vesicles (SVs) or synaptic-like microvesicles (SLMVs) in neuroendocrine cells transport non-peptide neurotransmitters, large dense-core vesicles (LDCVs) or secretory granules (SGs) in neuroendocrine cells store neuropetides and biogenic amines, whereas small dense-core vesicles (SDCVs) carry biogenic amines alone. These types of vesicles share a number of common membrane constituents, although they differ considerably in their biogenesis (Huttner et al., 1995; Winkler, 1997).

Biogenesis of SDCVs is poorly understood (Winkler, 1997). Most likely, however, they are thought to be 'hybrid' vesicles assembled from components of SVs and LDCVs in early endosomes (Huttner et al., 1995). Mature LDCVs are formed from immature secretory granules, which originate directly from TGN. Thus, LDCVs are delivered to the terminal fully assembled. In contrast, individual constituents of the SVs are transported from TGN to the plasma membrane at the neurite terminal by a constitutive pathway as components of precursor organelles. After endocytosis, followed by sorting and budding element, tryptophan W405 and leucine L408, that are critical for correct targeting of synaptotagmin II to neurite terminals. Changing either one of them to alanine prevents the accumulation of the protein at the terminals. These amino acids are evolutionarily conserved throughout the entire synaptotagmin family and also among synaptotagmin-related proteins, suggesting that different synaptotagmins may have similar mechanisms of targeting to neuronal cell terminals.

Key words: Synaptotagmin, PC12 cell, Neurite terminal, Protein targeting from early endosomes, they become components of mature $\mathrm{SVs}$, which undergo multiple rounds of recycling at the active presynaptic terminal (Kelly and Grote, 1993; Rothman, 1994; Südhof, 1995; Calakos and Scheller, 1996; De Camilli and Takei, 1996).

It is believed that SVs precursor organelles are delivered to the terminals by microtubule-based fast anterograde transport (Goodson et al., 1997; Hirokawa, 1998). However, precise itineraries of various components of SVs remain unclear and may vary. Several reports indicate that protein components of the presynaptic terminal are already sorted in the cell body into different classes of transport organelles and are delivered to the assembly site at the terminal by specific motor proteins. For instance, synaptic vesicle proteins synaptotagmin, synaptophysin, and SV2 expressed in non-neuronal cells are sorted independently into different cellular compartments (Feany et al., 1993). Moreover, synaptotagmin, synaptophysin, and Rab3A are sorted into a different class of precursor organelles and are transported to the nerve terminals by different motor proteins, and probably, via different routes than SV2 and certain components of the presynaptic plasma membrane. These differential modes of transport may reflect the functional differences between the various synaptic components (Okada et al., 1995).

Direct comparison of the primary sequences of synaptic vesicle proteins does not reveal any motif that could serve as a universal targeting signal. This may indicate that each protein component of SVs is delivered to the assembly site by a distinct 
specialized transport system. Alternatively, it is possible that each of the general transport systems interacts with several different species of synaptic protein cargo. Finally, targeting motifs may be present in only certain proteins, which then serve to direct several other assembled protein components of the precursor organelle to their destination.

We sought to identify targeting signals in synaptotagmins, which are obligatory constituents of SVs and LDCVs in neurons and their analogs in neuroendocrine cells. Synaptotagmins are multifunctional components of the regulatory secretory machinery in neuronal cells involved in exo- and endocytosis (Südhof, 1995; Südhof and Rizo, 1996; Geppert and Südhof, 1998; Schiavo et al., 1998). Synaptotagmins are a large family of integral type I membrane proteins identified to date in a wide spectrum of vertebrate and invertebrate species and represented in mammals by at least twelve distinct genes. Synaptotagmins are enriched in neurons and neuroendocrine cells. Some synaptotagmin isoforms are neuronal-specific, although their distribution in the nervous system is isoform-specific. Other isoforms are expressed ubiquitously. Synaptotagmins are structurally conserved and possess several domains (Perin et al., 1990, 1991a,b; Fig. 1A). A short amino-terminal $\mathrm{N}$-glycosylated intravesicular domain is followed by a single transmembrane domain and extended cytoplasmic region. A large part of the $\mathrm{C}$-terminal region contains a tandem region of the $\mathrm{Ca}^{2+}$-regulatory $\mathrm{C} 2 \mathrm{~A}$ and $\mathrm{C} 2 \mathrm{~B}$ domains separated by a short linker domain. A stretch of charged amino acids (charged domain) connects the $\mathrm{C} 2 \mathrm{~A}$ domain with the transmembrane domain. The $\mathrm{C} 2 \mathrm{~B}$ domain is followed by a short carboxy-terminal domain. The C2 domains, which mediate $\mathrm{Ca}^{2+}$-dependent membrane fusion, and the carboxy-terminal domain, for which no apparent physiological function has been described, show a remarkable degree of evolutionary conservation within different synaptotagmin isoforms and different organisms. This suggests that these domains may be involved in crucial protein-protein interactions. Indeed, synaptotagmins form numerous complexes with components of the synaptic vesicle and with cytoplasmic and plasma membrane proteins (Südhof and Rizo, 1996; Schiavo et al., 1998; Geppert and Südhof, 1998). These complexes may be important both for the functioning of the synaptic vesicle at the neuronal cell terminal, and for its delivery there.

To examine the signals that are required to target a protein molecule to the terminals of cultured neuronal cells, we tested the distribution of tagged recombinant synaptotagmin II molecules in neuroendocrine rat adrenal medula derived pheochromocytoma PC12 cells (Greene et al., 1987), neuronally differentiated after treatment with nerve growth factor (NGF). PC12 cells synthesize most membrane proteins that participate in regulated secretion in neurons, and contain at least two types of secretory vesicles, acetylcholinergic SLMVs and catecholaminergic and peptidergic secretory vesicles (Cutler and Cramer, 1990; Clift-O'Grady et al., 1990; Bauerfeind et al., 1993; Marxen et al., 1997). In this aspect, PC12 cells are similar to the adrenergic sympathetic neurons, which originate from the same precursor. After treatment with NGF, PC12 cells develop extended neurites, which resemble axons more than dendrites. In particular, neurite terminals and varicosities of PC12 cells are enriched with both types of secretory vesicles (Lah and Burry, 1993; Elferink et al., 1993;
Hudson et al., 1993). Furthermore, similar to axons, neurites of PC12 cells are devoid of ribosomes, enriched with growth cone-specific protein GAP43, and depleted of dendrite-specific protein MAP2. In addition, axon-specific tau and MAP1 proteins are induced in these cells before extension of neurites (for ref. see Kelly and Grote, 1993; Bonzelius et al., 1994).

Here we demonstrate that a distinct element located in the carboxy-terminal domain of the synaptotagmin molecule is necessary for its proper targeting to the neurite terminal. Mutations in this area prevent accumulation of the protein at the terminal; in particular, two amino acids are absolutely essential for correct targeting. These two indispensable amino acids are evolutionarily conserved among all known synaptotagmin isoforms and synaptotagmin-related proteins, and may represent the crucial points of contact with the transport machinery of neuronal cell.

\section{MATERIALS AND METHODS}

\section{Antibodies}

Monoclonal antibodies (mAb) directed against influenza virus hemagglutinin epitope (anti-HA, clone 12CA5; Field et al., 1988) were purified from mouse ascite fluid on a low-salt Protein ASepharose 4B (Sigma) column as described (Harlow and Lane, 1988). Mouse mAb against rat synaptotagmin I (clone 41.1; Brose et al., 1992) were a gift from Reinhard Jahn (Yale University School of Medicine). Mouse anti-synaptophysin (clone SVP-38) and antisyntaxin 1a (clone HPC-1) mAb were obtained from Sigma. Sheep anti-mouse biotinylated Ig, streptavidin-horseradish peroxidase conjugate, and streptavidin-Texas Red conjugate were purchased from Amersham.

\section{Plasmid constructions}

Standard molecular cloning procedures were as described (Maniatis et al., 1989). Plasmid pCMV65-8 containing a $2.7 \mathrm{~kb}$ EcoRI/XbaI insert of the full-length rat synaptotagmin II cDNA (Geppert et al., 1991) was a gift from Thomas Südhof (University of Texas, Southwestern Medical Center at Dallas). Using appropriate restriction sites and short PCR-generated fragments, the synaptotagmin II coding region was recloned into a pUC19-based eukaryotic expression vector pRSV containing $0.55 \mathrm{~kb}$ of the RSV promoter/enhancer region and $2.3 \mathrm{~kb}$ sequence of the rabbit $\beta$-globin gene fragment bearing splicing/polyadenylation signal sites. The carboxy terminus of the synaptotagmin II was fused with two copies of the influenza virus hemagglutinin (HA) epitope (Field et al., 1988). In this fusion construct (Syt-HA), the stop codon of synaptotagmin II was omitted, and the $5^{\prime}$-untranslated region (115 bp) was left unchanged. The structure of the 39 amino acids tag fragment was LEASPPSSYPYDVPDYASLGGPSSYPYDVPDYASLGGPS. This sequence is followed by two stop codons preceding the $\beta$-globin gene fragment. A chain-breaking $\boldsymbol{P P}$ motif was used to connect the tag to the rest of the protein; the sequence LEAS represents neighboring unique $\mathrm{XhoI} / \mathrm{NheI}$ restriction sites.

Syt-HA subclones with random carboxy-terminal truncations of synaptotagmin were generated essentially as described (Lin et al., 1985). In the presence of $\mathrm{Mn}^{2+}$, SytII-HA-containing plasmid DNA was subjected to DNase I treatment limited by single-cut cleavage. DNA was cleaved at a NheI site, and after filling in with Klenow DNA polymerase, was self-ligated. Prior to $E$. coli cells transformation, DNA was treated at XhoI site to abolish the background of original molecules. Subclones were analyzed using PCR-based bacteria colonies screening and DNA sequencing. Syt-HA-based constructs with directed carboxy terminus synaptotagmin deletions and constructs with deletions of internal synaptotagmin fragments were 
prepared using convenient restriction sites and short PCR fragments generated from synthetic primers. Similarly, alanine-scanning mutagenesis was performed using PCR and primers containing the desired mutations. The structure of each clone generated with PCR was confirmed by DNA sequencing.

\section{Cell culture and transient expression}

PC12 cells were obtained from Lloyd Greene (Columbia University) and maintained as an early passage stock. Cells were grown on collagen (Upstate Biotechnology)/poly-D-lysine (Sigma)-coated plates in DMEM supplemented with heat-inactivated $10 \%$ calf and $5 \%$ horse sera (HyClone) in the presence of $100 \mathrm{U} / \mathrm{ml}$ penicillin and $100 \mathrm{U} / \mathrm{ml}$ streptomycin. For neuronal differentiation, cells were treated with $50 \mathrm{ng} / \mathrm{ml}$ of $2.5 \mathrm{~S}$ NGF (mouse) (Upstate Biotechnology) 5 days before and 2 days after transfection. For transient expression, cells were transfected by electroporation. Cells were grown with or without NGF to a density of $10-15 \times 10^{6}$ per $10 \mathrm{~cm}$ plate. All the following steps were performed at room temperature (RT). After harvesting at $1300 \mathrm{rpm}$ for 10 minutes, cells were resuspended in fresh medium to a final density of $6 \times 10^{6}$ per $\mathrm{ml}$ for immunofluorescent analysis, or $30 \times 10^{6}$ per $\mathrm{ml}$ for biochemical experiments. $250 \mu \mathrm{l}$ of cell suspension was mixed in an $0.4 \mathrm{~cm}$ electroporation cuvette (Bio-Rad, Hercules, CA) with $20-40 \mu \mathrm{g}(500 \mu \mathrm{g} / \mathrm{ml})$ of plasmid DNA (Qiagen or $\mathrm{CsCl}$ purified) and electroporation was performed at $230 \mathrm{~V}, 960 \mu \mathrm{F}$ (Gene Pulser, Bio-Rad). The cell suspension was then transferred from the cuvette to a centrifugation tube preloaded with $20 \mathrm{ml}$ of medium. After harvesting, the cells were resuspended in an appropriate volume of the medium with or without NGF and plated on $3.5 \mathrm{~cm}$ plates supplemented with collagen/poly-D-lysine-coated coverslips for immunofluorescence analysis or on $10 \mathrm{~cm}$ coated plates for biochemical experiments $\left(0.75 \times 10^{6}\right.$ or $7.5 \times 10^{6}$ per plate, respectively). For subsequent analysis, cells were used in 2 days. Routinely, the efficiency of transfection was $10-15 \%$.

\section{Subcellular fractionation}

Transfected NGF-differentiated PC12 cells $\left(30 \times 10^{6}\right)$ were rinsed twice with PBS at RT, dislodged from the plates by scraping into 10 $\mathrm{ml}$ of the cold homogenization buffer $(0.2 \mathrm{M}$ sucrose, $50 \mathrm{mM} \mathrm{NaCl}$, $2 \mathrm{mM}$ EGTA, $10 \mathrm{mM}$ Tris-HCl, $\mathrm{pH}$ 7.4) supplemented with protease inhibitors (PI; $1 \mu \mathrm{g} / \mathrm{ml}$ aprotinin, $1 \mu \mathrm{g} / \mathrm{ml}$ leupeptin, $1 \mu \mathrm{g} / \mathrm{ml}$ pepstatin, $1 \mathrm{mM}$ PMSF), and pelleted at 32,500 $\mathrm{g}(20,000 \mathrm{rpm})$ for 20 minutes (JA20 rotor). The pellet was resuspended in $2.0 \mathrm{ml}$ of the homogenization buffer and homogenized with a motor-driven Teflonglass homogenizer (700 rpm, 20 strokes). The centrifugation was performed at $1000 \mathrm{~g}$ (3500 rpm, Eppendorf) for 10 minutes, and $1 \mathrm{ml}$ of post-nuclear supernatant was loaded on the top of a $12 \mathrm{ml}$ linear sucrose density gradient $(0.2-2.3 \mathrm{M})$ containing $50 \mathrm{mM} \mathrm{NaCl}, 2 \mathrm{mM}$ EGTA and $10 \mathrm{mM}$ Tris- $\mathrm{HCl}(\mathrm{pH}$ 7.4). The centrifugation was performed at 38,000 rpm $\left(178,200 \mathrm{~g}_{\mathrm{AV}}\right)$ for 15 hours (SW 41.1 rotor, Beckman); $0.5 \mathrm{ml}$ fractions were collected from the bottom of the tubes.

\section{SDS-PAGE samples preparation and protein determination}

Subcellular fractions or whole cell suspensions were aliquoted and stored at $-80^{\circ} \mathrm{C}$. Aliquots were mixed with an equal volume of $2 \times$ SDS-buffer (4\% SDS, $120 \mathrm{mM}$ Tris- $\mathrm{HCl}, \mathrm{pH}$ 6.8) supplemented with PI. To disrupt DNA, lysates were passed three times through a 26-gauge needle. Then, samples were boiled for 4 minutes and centrifuged at 15,000 rpm for 5 minutes at RT. Protein determination was performed using BCA reagent system (Pierce). When necessary, the assay was performed with DTT-containing samples. To avoid DTT influence, before the assay, samples were subjected to quantitative precipitation with $10 \times$ excess of $n$-butanol in the presence of glycogen (Boehringer Mannheim) as a carrier. Precipitates were washed twice with acetone and dissolved in desired volume of $100 \mathrm{mM} \mathrm{NaOH}$. For sodium dodecylsulfate gel electrophoresis (SDS-PAGE), lysats were mixed with $1 / 3$ volume of
$50 \%$ glycerol containing DTT (150 mM finally) and Bromophenol Blue and boiled for 4 minutes.

\section{SDS-PAGE immunoblotting}

SDS-PAGE was performed on $8.5 \%$ or $12.5 \%$ polyacrylamide gels. After equilibration for 15 minutes in transfer buffer ( $48 \mathrm{mM}$ Tris, 39 $\mathrm{mM}$ glycine, $0.0375 \%$ SDS, $20 \%$ methanol, $\mathrm{pH}$ 9.2; Harlow and Lane, 1988), proteins were transfered from the gel to the Immobilon-P membrane (Millipore) using a semi-dry blotting system (Bio-Rad) for 1.5 hours at $15 \mathrm{~V}$. Then, the membrane was washed $3 \times 10$ minutes with PBS and blocked overnight with 5\% non-fat dry milk in PBS at $4^{\circ} \mathrm{C}$. All the following steps were performed at RT. The membrane was washed $3 \times 10$ minutes with PBS and incubated for 1 hour with $\mathrm{mAb}$ (dilution 1:400 for anti-HA or 1:1000 for anti-synaptotagmin, anti-synaptophysin, and anti-syntaxin) in PBS-T-BSA (PBS, $0.05 \%$ Tween-20, 1\% BSA) in the presence of $1 \%$ normal sheep serum (Sigma). The membrane was next rinsed twice and washed $3 \times 10$ minutes with PBS-T (PBS, $0.05 \%$ Tween-20), and incubated for 1 hour with sheep anti-mouse biotinylated Ig (dilution 1:1000) in PBST-BSA. Then, the membrane was washed as above and incubated for 1 hour with streptavidin-horseradish peroxidase conjugate $(1: 1000$ dilution) in PBS-T-BSA. After washing with PBS-T, the membrane was rinsed with PBS and reactive bands were detected using ECL system (Amersham).

\section{Immunofluorescence staining}

Cells transfected with synaptotagmin-HA encoding constructs or nontransfected cells were stained with anti-HA or anti-synaptotagmin $\mathrm{mAb}$, respectively. Cells were fixed on coverslips with $4 \%$ methanolfree formaldehyde (Polysciences) in PBS for 20 minutes, washed $3 \times$ 10 minutes with PBS-G (PBS, $100 \mathrm{mM}$ glycine) at RT, permeabilized for 10 minutes with $0.1 \%$ Triton $\mathrm{X}-100$ in PBS-G at $0^{\circ} \mathrm{C}$, washed $3 \times$ 10 minutes with PBS, and incubated for 30 minutes in PBS-T-BSA containing $1 \%$ normal sheep serum. Then cells were incubated for 1 hour in the same solution with mAb (dilution 1:50 for anti-HA or 1:100 for anti-synaptotagmin), washed $3 \times 10$ minutes with PBS-T and 10 minutes with PBS-T-BSA, and incubated for 1 hour in the same solution with sheep anti-mouse biotinylated Ig (dilution 1:100). For control of background staining, $\mathrm{mAb}$ were omitted or anti-HA mAb were applied to non-transfected cells. After washing as above, cells were incubated for 1 hour with streptavidin-Texas Red (dilution 1:100) in PBS-T-BSA, and washed $3 \times 10$ minutes with PBS-T and $2 \times$ 10 minutes with PBS. Coverslips were rinsed with water and mounted with Gel/Mount medium (Biomeda). Cells were analyzed by two observers independently with a Zeiss Axiophot fluorescence microscope equipped with a $\times 40$ Plan-Neofluar objective and photographed using Kodak T64 color slide film. For each transfected construct, over 25 images from at least 3 separate transfection experiments were obtained. Representative images were processed with Nikon Coolscan slide scanner and assembled with Adobe Photoshop. For quantitative analysis, cell images were processed using Scion Image. For each image (10 images per case), the average pixel intensities of the terminals $(T)$, the cell body $(C)$, and of the background $(B)$ were measured, and the average ratio $R=(T-B) /(C$ $B)$ was calculated.

\section{RESULTS}

\section{Recombinant synaptotagmin is correctly targeted in transfected PC12 cells}

Synaptotagmins have a highly specific distribution in neurons, and the highest concentrations are observed at the axon terminals (Matthew et al., 1981; Matteoli et al., 1991; Wendland et al., 1991; Ramaswami et al., 1994) and also in the 
A

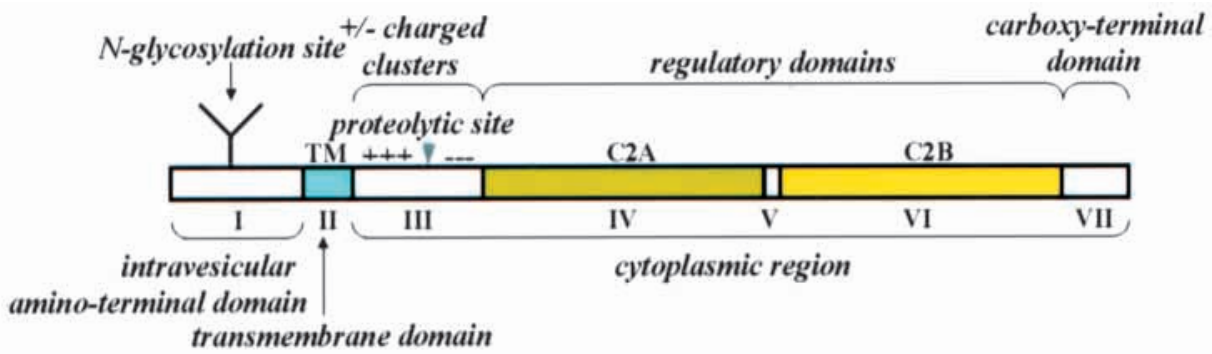

Syt-HA
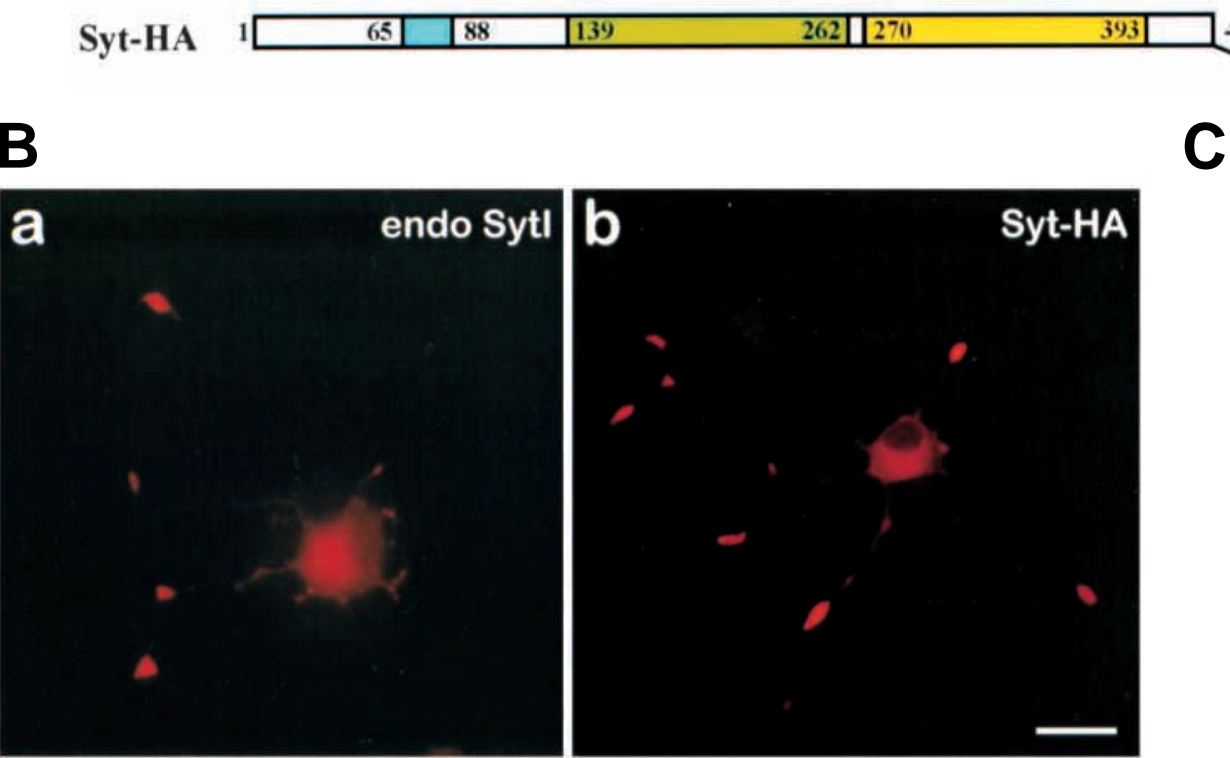

a

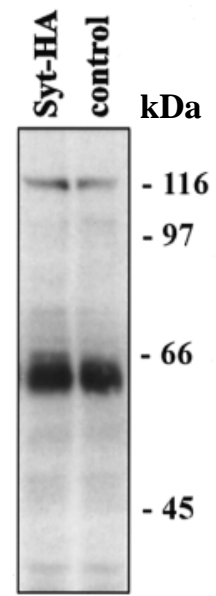

anti-Syt Ab b

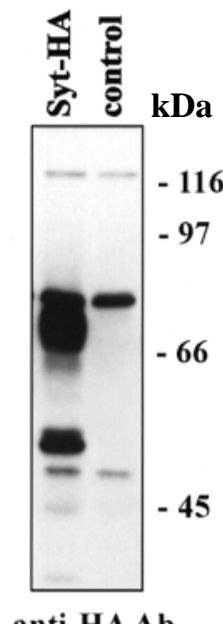

cells. (A) Synaptotagmin domain structure and schematic representation of the carboxyterminal rat synaptotagmin II fusion construct with HA-epitopes, Syt-HA. Domains are numbered according to Südhof and Rizo (1996); rat synaptotagmin II domain borders are mapped according to Geppert et al. (1991). (B) Immunofluorescence staining of NGF-differentiated PC12 cells: (a) non-transfected cells labeled with anti-SytI mAb (41.1); (b) cells transfected with Syt-HA and labeled with anti-HA mAb (12CA5) 48 hours after transfection. Similar images were captured from at least 10 (a) and 25 (b) other cells. Bar, $25 \mu \mathrm{m}$. (C) Expression of Syt-HA: SDS-PAGE immunoblotting of whole cell SDS-lysates of non-differentiated PC12 cells. An equal amount of total protein from transfected and control non-transfected cells was loaded (10 $\mu \mathrm{g} / \mathrm{lane}) ; 8.5 \%$ PAGE: (a) anti-SytI mAb (41.1); (b) anti-HA mAb (12CA5). Note that none of the anti-HA reactive bands are recognized by anti-Syt I mAb (41.1), indicating that these antibodies are highly selective for synaptotagmin I and do not cross-react with synaptotagmin II.

region of the Golgi complex (Matteoli et al., 1991; Hou et al., 1997). In neuronally differentiated PC12 cells, synaptotagminspecific antibodies recognize proteins with a similar distribution (Elferink et al., 1993; Marxen et al., 1997), and most of the immunoreactivity with anti-SytI $\mathrm{mAb}$ (clone 41.1; Brose et al., 1992) was observed at the terminals and varicosities of extended neurites and in the region of the Golgi complex (Fig. 1B,a).

To test whether recombinant synaptotagmin has a comparable distribution and to discriminate it from endogenous synaptotagmin, we prepared cDNA construct coding for rat synaptotagmin II (Geppert et al., 1991) tagged with HA-epitopes (Field et al., 1988). In this construct (SytHA), two copies of the HA-epitope were fused to the carboxy terminus of synaptotagmin II (Fig. 1A). In total, 39 amino acids were added to the full-length (422 amino acids) synaptotagmin II. This chimeric cDNA was placed under the control of the RSV promoter, and recombinant construct was introduced by electroporation into PC12 cells neuronally differentiated by NGF. The cellular distribution of recombinant tagged synaptotagmin molecules was monitored by immunofluorescence after incubation with anti-HA mAb. Since the time required for full differentiation of PC12 cells after addition of NGF (7-10 days) is much longer than the time required for optimal expression of the transfected synaptotagmin gene (2-3 days; data not shown), we used primed PC12 cells that had undergone NGF treatment for 5-6 days before transfection (Greene et al., 1987). When such cells 
were detached from the substrate, subjected to electroporation, and replated in the presence of NGF, they restored neurites within a very short time, and after 2-3 days, most of the cells $(>90 \%)$ had multiple branched extended neurites and were indistinguishable from cells that have been exposed to NGF continuously for 7-9 days. Likewise, the distribution of endogenous synaptotagmin molecules in primed cells was the same as in regular neuronally differentiated PC12 cells (data not shown). This approach enabled us to combine the neuronally differentiated status of PC12 cells with the high level of expression of recombinant synaptotagmin. When primed PC12 cells were transfected with the Syt-HA construct and labeled with anti-HA mAb (Fig. 1B,b), staining revealed a highly specific distribution of the tagged protein, with strong enrichment in neurite terminals and varicosities. Except for the terminals, neurites themselves were usually poorly stained. Noteworthy, the length of the processes did not affect the level of enrichment of immunoreactivity in the terminals. In the cell bodies, most of the immunoreactivity was concentrated in the region of the Golgi complex, whereas other parts of the cytoplasm were less stained, and the cell nuclei were free of HA-immunoreactivity. Preferential accumulation of Syt-HA molecules at the terminals was further confirmed by confocal microscopy of transfected cells (data not shown), and the overall staining pattern was found to be similar to the distribution of endogenous synaptotagmin I in non-transfected differentiated PC12 cells (Fig. 1B,a). These visual assessments are supported by the results of quantitative image analysis. From the analysis, the mean ratio $R$ of the average pixel intensities of the terminals to the average pixel intensities of the cell bodies was 1.79 (s.e.m. $=0.06$ ) for the cells transfected with Syt-HA and stained with anti-HA antibodies, and 1.55 (s.e.m. $=0.06)$ for the non-transfected cells stained with antiSytI antibodies for endogenous synaptotagmin. These values are comparable, although the difference between them is statistically significant $(P<0.01$; unpaired $t$-test $)$.

To further study the expression of recombinant synaptotagmin constructs, we prepared whole cell SDS-lysates from PC12 cells transfected with Syt-HA and from nontransfected control cells. Proteins were examined by immunoblotting using anti-Syt I or anti-HA mAb (Fig. 1C, a and $b$, respectively). Anti-Syt I antibodies recognized a diffuse band of endogenous synaptotagmin I in both non-transfected and transfected cells. The band had an apparent mobility of 60$62 \mathrm{kDa}$ and migrated more slowly in SDS-PAGE than its length would predict, as described (Perin et al., 1991b). Uneven distribution of charged residues along the synaptotagmin molecule together with glycosylation (Perin et al., 1991b; Geppert et al., 1991; Tugal et al., 1991) and fatty acylation (Veit et al., 1996; Chapman et al., 1996) contribute to the anomalous mobility of synaptotagmins in SDS-PAGE. When lysates from Syt-HA-transfected cells were probed with antiHA antibodies, a major diffuse 70-72 kDa band, corresponding to the HA-tagged synaptotagmin II molecule, was observed (the change in mobility is due to the appended HA-epitope). In addition, a less intensive band of $52 \mathrm{kDa}$ was visible. This band represents the cytoplasmic region of the protein and corresponds to the major proteolytic fragment of Syt I (positions 112-421) after cleavage of the hypersensitive site in the charged domain (III) (Perin et al., 1991b; Tugal et al., 1991). Two background bands of $\sim 80$ and $\sim 48 \mathrm{kDa}$, which were present in all lanes including lysates from non-transfected cells, correspond to the endogenous anti-HA mAb-reactive proteins. Since only a small fraction of cells was transfected (routinely, 10-15\%), these background proteins did not contribute to the immunofluorescence signal. Thus, immunoreactivity in the transfected cells is due to the correct form of the tagged synaptotagmin molecule. Identical results were obtained when SDS-lysates from NGF-differentiated and naïve cells were analyzed after transfection with Syt-HA construct (data not shown), suggesting that differentiation status does not affect expression and stability of recombinant synaptotagmin fusion molecules.

When the HA-epitopes were located at the amino terminus of the recombinant protein (HA-Syt version), protein was expressed at much lower levels than the Syt-HA protein (data not shown), suggesting that extension of the synaptotagmin amino terminus with HA-epitopes leads to decreased stability of such a protein. Its distribution did not resemble that of endogenous synaptotagmin and the Syt-HA version. In this case, anti-HA immunoreactivity was rather diffusely distributed over the entire cell bodies, but was not detected at the tips of the neurites (data not shown).

Thus, expression, processing, and distribution of the carboxy-terminal (but not amino-terminal) fusion of synaptotagmin II with HA-epitopes accurately reflect the fate of endogenous synaptotagmin molecules in PC12 cells. We conclude that this system is adequate for studying structural elements of the synaptotagmin molecule, which may account for its accumulation at neurite terminals.

\section{Carboxy-terminal domain is necessary for the accumulation of synaptotagmin at neurite terminals}

We have generated an extensive series of random truncations of the synaptotagmin portion of the Syt-HA, extending from the carboxy-terminal domain to the intravesicular domain. Of the 92 subclones analyzed, 29 contained truncated synaptotagmin sequences in frame with the HA-epitope. Sixteen deletion variants evenly covering the entire synaptotagmin molecule (Fig. 2A) were introduced into PC12 cells for immunofluorescence and immunoblotting analyses.

Fig. 2B shows a SDS-PAGE immunoblotting of lysates of PC12 cells transfected with truncated Syt-HA mutants after incubation with anti-HA antibodies. Almost all constructs with deletions covering the carboxy-terminal, C2B, C2A, and the charged domains (VII, VI, IV, and III) were expressed at high levels and produced polypeptides of the expected length. However, when truncations covered domain III, the proteins were less stable. The shortest constructs $(82 \Delta 340$ and $45 \Delta 377)$ with truncations extending to the transmembrane domain (II) and the intravesicular domain (I) were unstable and produced only faint low-molecular weight bands. Most of the longer constructs contained an additional band (52 kDa for Syt-HA full-length, $422 \mathrm{wt}$ ) resulting from the cleavage of the hypersensitive proteolytic site in the charged domain. Furthermore, constructs in which truncations were terminated in the carboxy-terminal domain $(\Delta 27)$ or the upstream $\mathrm{C} 2 \mathrm{~B}$ domain ( $\Delta 179$ and further), but not within C2B $(\Delta 69-\Delta 150)$, produced additional polypeptides with lower mobility resulting from yet another unidentified cleavage site(s) (see also below).

Fig. 2C shows representative examples of neuronally differentiated PC12 cells transfected with HA-tagged full- 
length and truncated variants of Syt-HA and stained with anti-HA antibodies. Full-length protein (422 wt) was accumulated in the tips and varicosities of the neurites (a), as described above. However, deletion of as few as 27 amino acids from the carboxy terminus of the synaptotagmin portion of the fusion protein (construct 395 227 ) blocked its accumulation at neurite terminals and varicosities, although the pattern of staining of the cell bodies was not changed (b). In this case, the value of the mean ratio $(R)$ of the average pixel intensities of the terminals to the average pixel intensities of the cell bodies was 0.29 (s.e.m. $=0.03$ ) compared with 1.79 (s.e.m. = 0.06) for full-length protein. Such a difference (about 6 fold) is statistically significant $\quad(P<0.001$; unpaired $t$-test) and thus supports our assessments based on the visual

Fig. 2. Synaptotagmin carboxy-terminal truncation mutants: expression and intracellular localization in PC12 cells. (A) Schematic representation of Syt-HA subclones with random truncations of synaptotagmin II carboxy terminus. (B) Expression of Syt-HA truncated subclones. SDS-PAGE immunoblotting of whole cell SDS-lysates of transfected and control non-differentiated PC12 cells; anti-HA mAb. An equal amount of total protein was loaded $(10 \mu \mathrm{g} / \mathrm{lane})$ :

(a) $8.5 \%$ PAGE; (b) $12.5 \%$ PAGE.

$(\mathrm{C}, \mathrm{a}, \mathrm{b}, \mathrm{c})$ Immunofluorescence staining of NGF-differentiated PC12 cells transfected with Syt-HA truncated subclones and labeled with anti-HA $\mathrm{mAb}$. In each case, similar images were captured from over 25 other cells in at least 3 independent experiments. Bar, $25 \mu \mathrm{m}$.

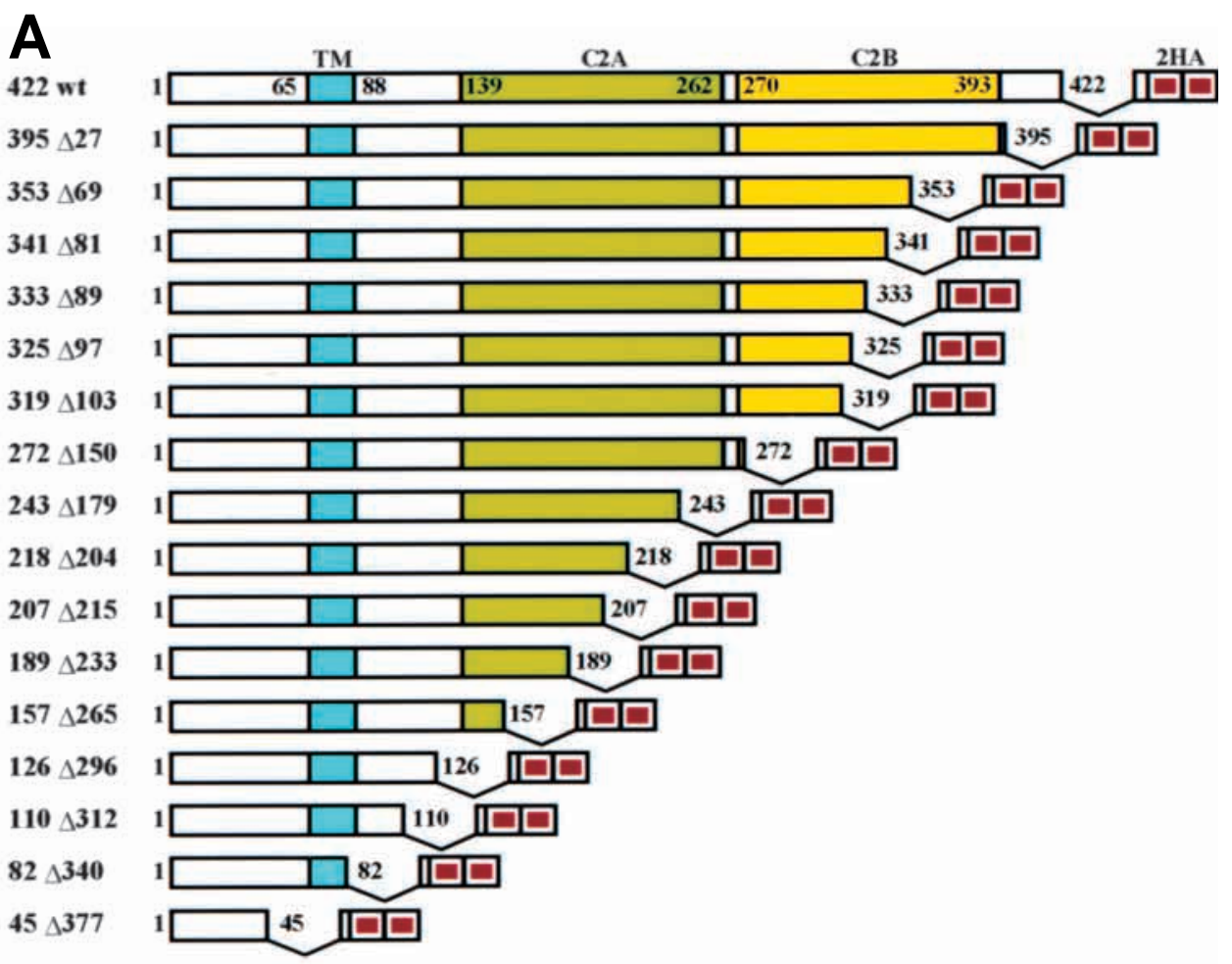

$\mathbf{a}$

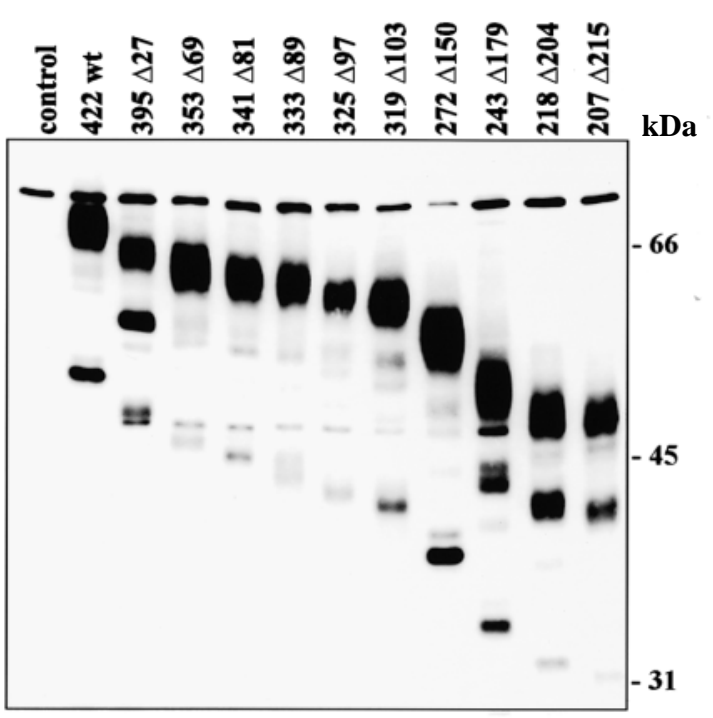

b
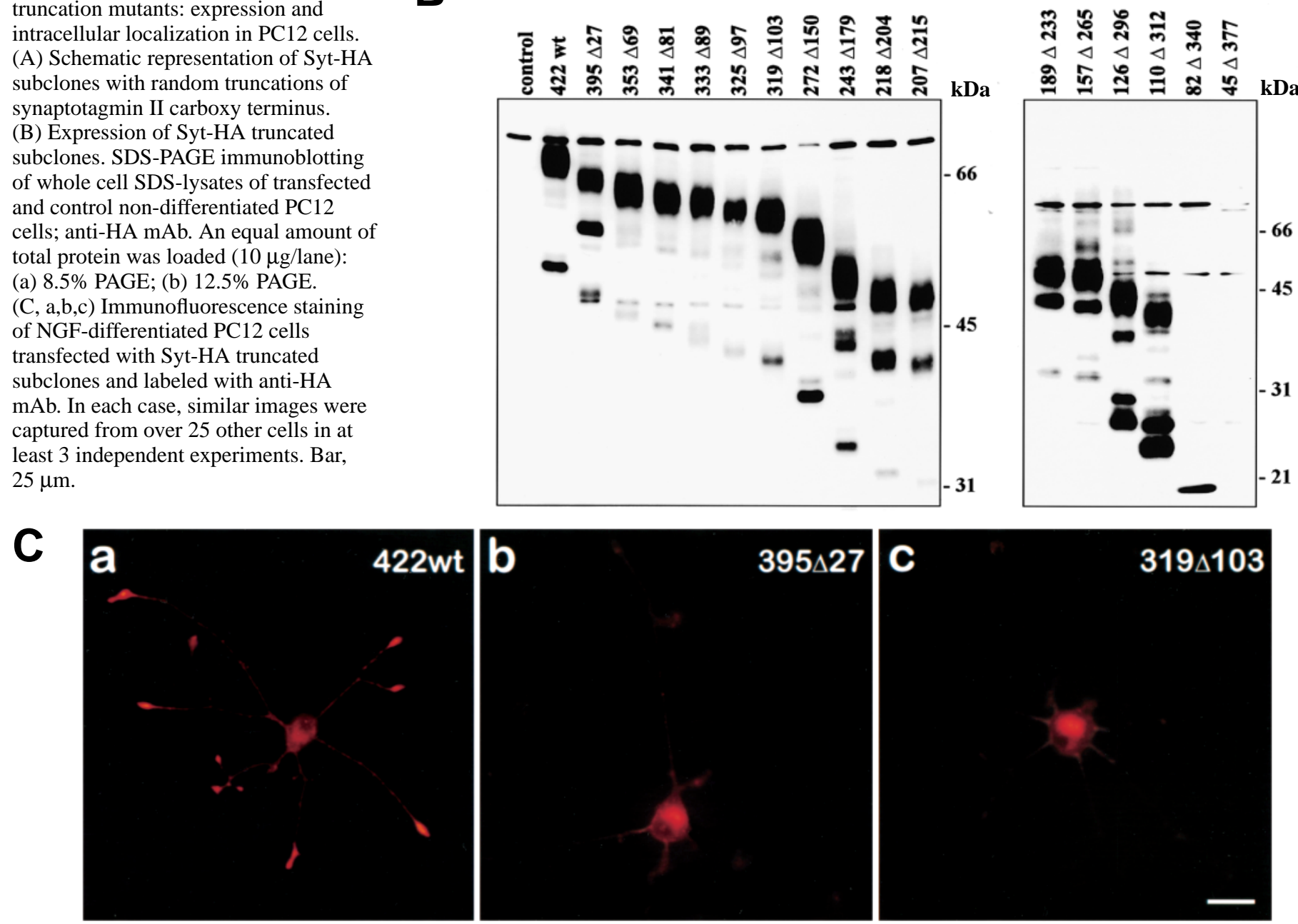

$319 \Delta 103$ 


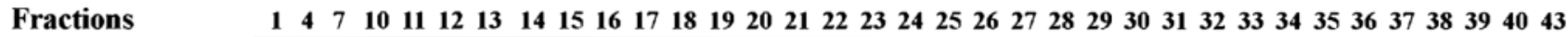

422 wt

$319 \Delta 103$

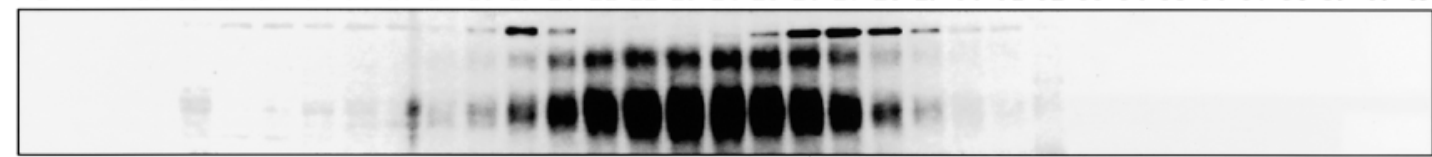

Synaptotagmin I

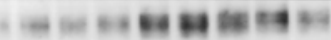

Synaptophysin

Syntaxin
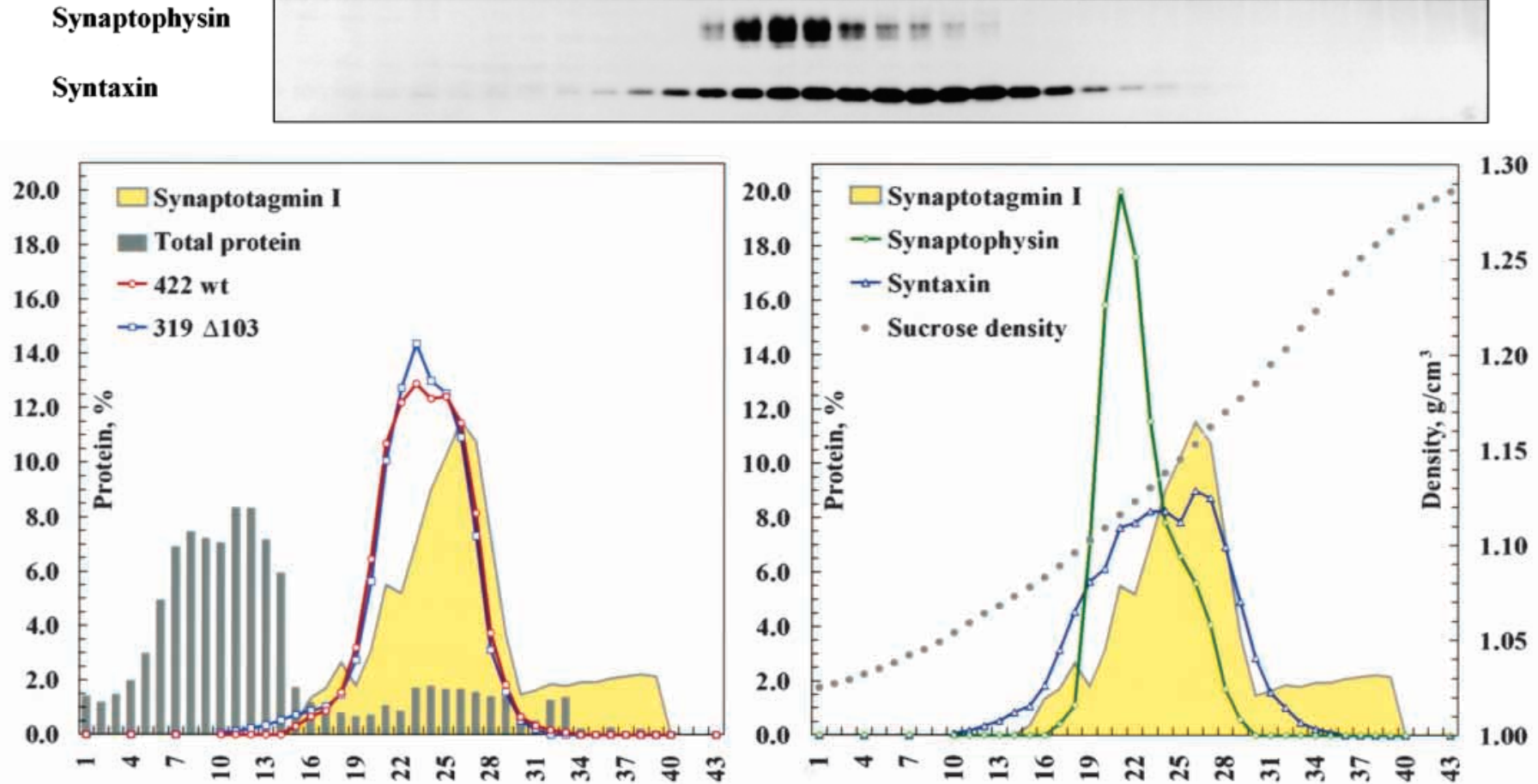

Fig. 3. Subcellular fractionation of transfected NGF-differentiated PC12 cells. Two cell pools were separately transfected with full length SytIIHA (wt) and its carboxy terminus truncated variant $319 \Delta 103$, mixed together and plated. After 48 hours, a post-nuclear supernatant was prepared and subjected to linear sucrose density gradient (0.2-2.3 M) fractionation. Gradient fractions were examined with SDS-PAGE immunoblotting (8.5\% PAGE) using anti-HA (12CA5), anti-synaptotagmin I (41.1), anti-synaptophysin (SVP-38), and anti-syntaxin 1a (HPC1) $\mathrm{mAb}$. An equal volume from each fraction was loaded. Fractions are numbered from the top to the bottom of the gradient. Immunoblots were scanned and analyzed using Scion Image. The amount of proteins in each fraction is expressed as a percentage of their total amount in all fractions. Density of fractions was determined by refractive index. Density of fractions containing maximum immunoreactivity of synaptophysin was $1.12 \mathrm{~g} / \mathrm{cm}^{3}$; of synaptotagmin I, $1.12 \mathrm{~g} / \mathrm{cm}^{3}$; and of both recombinant HA-tagged synaptotagmin II and its truncated mutant, $1.13 \mathrm{~g} / \mathrm{cm}^{3}$.

analysis of large number of cells transfected with this and other constructs (see below).

Progressive truncation of the sequences containing fragments of $\mathrm{C} 2 \mathrm{~B}$ and $\mathrm{C} 2 \mathrm{~A}$ domains did not result in any further noticeable changes in the distribution of the recombinant protein in the cells (Fig. 2C, c, and data not shown) in comparison with construct 395 27 . A similar pattern was revealed when the truncations were extended to the charged and the transmembrane domains (data not shown), although in this case, the staining may reflect the distribution of degradation fragments (Fig. 2B,b).

These data strongly indicate that determinants required for the accumulation of synaptotagmin to the neurite terminals are located in the carboxy-terminal domain of the molecule. To further examine the constructs that do and do not contain the carboxy-terminal targeting determinants, we performed subcellular fractionation of extracts from cells transfected with the full-length construct Syt-HA (422 wt) and one of its truncated variants $(319 \Delta 103)$. This truncated mutant lacks 103 amino acids from the carboxy terminus and does not accumulate at the neurite terminals (Fig. 2C,c); the difference in length between the full-length and truncated variants permits their separation by SDS-PAGE and subsequent simultaneous detection by immunoblotting. To ensure identical conditions for fractionation of both versions of Syt-HA, we transfected PC12 cells with $422 \mathrm{wt}$ and $319 \Delta 103$ constructs separately, mixed the cells together, and plated. After disrupting this mixed population of cells and centrifuging at low speed, organelles from the post-nuclear supernatant were separated on a 0.2-2.3 M linear sucrose density gradient and gradient fractions were analyzed by immunoblotting with antibodies against HA-epitope, synaptotagmin I, synaptophysin, and syntaxin 1a (Fig. 3).

Endogenous synaptotagmin I, which is present in both SLMVs and in the secretory granules (Trifaro et al., 1989; Perin et al., 1991b; Schmidle et al., 1991; Walch-Solimena et al., 1993; Bonzelius et al., 1994), sedimented as a broad band after centrifugation, reflecting its bimodal distribution, 
although its main portion was located in more dense fractions (with the maximum at $1.15 \mathrm{~g} / \mathrm{cm}^{3}$ ) most likely containing secretory granules in accordance with earlier results (Schmidle et al., 1991; Bonzelius et al., 1994). Synaptophysin, which marks SLMVs (Clift-O'Grady et al., 1990; Walch-Solimena et al., 1993) as well as endosomes, migrated in a zone on the less dense shoulder of the synaptotagmin peak (with the maximum at $1.12 \mathrm{~g} / \mathrm{cm}^{3}$ ). A small portion of synaptophysin was also present in more dense fractions reflecting the presence of a low amount of synaptophysin in secretory granules of PC12 cells (for discussion see Winkler, 1997). Syntaxin was present in a broad zone across the gradient reflecting its association with both vesicles and plasma membranes (Walch-Solimena et al., 1995). Recombinant HA-tagged synaptotagmin II and its truncated mutant migrated in the same zone of the gradient as the endogenous synaptotagmin I. However, their content was higher in the zone of less dense fractions with the maximum at $1.13 \mathrm{~g} / \mathrm{cm}^{3}$, suggesting that both recombinant synaptotagmin variants were mostly associated with SLMVs or their precursors, rather than with secretory granules. No recombinant synaptotagmin was revealed in fractions of soluble proteins on the top of the gradient. It is also notable that the fractions with characteristic densities corresponding to the rough endoplasmic reticulum $\left(1.18-1.26 \mathrm{~g} / \mathrm{cm}^{3}\right.$; Spector et al., 1998) were substantially depleted of immunoreactivity of both wt and mutant recombinant synaptotagmins. Importantly, there was no difference in the distribution of the full-length and the truncated versions of Syt-HA, despite the fact that only the full-length protein, but not the truncated version, is correctly targeted to the neurite terminals.

These results indicate that both versions are incorporated into similar membrane organelles, and suggest that accumulation of the mutant form in the terminals is blocked not due to retention of newly synthesized protein molecules in the rough endoplasmic reticulum, but due to later events. This notion is also supported by the results of the immunostaining analysis showing that for both versions the staining of the cell bodies was concentrated mainly in the region of the Golgi complex whereas other parts of cytoplasm were usually less stained (Fig. 2C,a,c). This suggests that carboxy-terminal targeting determinants do not represent a sorting signal that directs the synaptotagmin molecule to the vesicles or their precursors. Therefore, they should be utilized by some other mechanisms which determine synaptotagmin accumulation at the neurite terminals.

There are examples of proteins, including synaptotagminrelated proteins, which are able to accumulate at the terminals but do not possess transmembrane domains. Among them is rabphilin-3A (Li et al., 1994) which shares extensive sequence similarity with synaptotagmin. To address the question if accumulation of synaptotagmin in the neurite terminals can be achieved without association with membrane organelles, we prepared a series of mutants with internal deletions in the transmembrane and also in the charged regions (domains II and III, respectively) (Fig. 4A). This area contains several determinants that are potential targets for important modifications and interactions, such as clusters of positively and negatively charged residues, including a cluster of lysine residues that can be a potential recognition site for proteases, and a group of conserved cysteine residues that can be substrates for palmitoylation. In addition, we prepared a mutant lacking both $\mathrm{C} 2$ domains and the short linker between them (domains IV, V, and VI).

When the expression of these constructs was tested by immunoblotting, some of the mutant proteins demonstrated faster mobility than was expected. Data in Fig. 4B indicate that amino acids in transmembrane domain II and charged residues in domain III contribute greatly to the abnormal mobility of synaptotagmin in SDS-PAGE. When either one of these domains (constructs 398 $\Delta 24(64-87), 383 \Delta 39(49-87)$, and $372 \Delta 50(89-138)$ ) or both of them (constructs $347 \Delta 75(64-138)$ and $332 \Delta 90(49-138)$ ) were removed, the mobility of recombinant proteins dropped dramatically and corresponded more closely to the predicted mobility (taking into account the appended HA-epitope and the effects of post-translational modifications). The immunoblotting results are also consistent with the notion (see above) that in addition to the main hypersensitive proteolytic site located in domain III, there may be another site(s). When the deletion covered domains II and III (construct 347 $\Delta 75(64-138)$ ) and thus the main hypersensitive proteolytic site was removed, the HA-tagged proteolytic fragment with mobility $\sim 42 \mathrm{kDa}$ was detected. The mobility of this fragment was increased when the deletion was extended to the 15 amino acids of the border of domain I (construct 332 $\Delta 90(49-138)$ ). This indicates the presence of a proteolytic site(s) in the intravesicular domain upstream of position 48. Fragments likely to have arisen from the same origin were also detected when $\mathrm{C} 2$ domains were deleted (construct 184\$238(145-382)). The presence of a proteolytic site in the intravesicular domain has already been suggested for synaptotagmin I (Tugal et al., 1991; Wendland and Scheller, 1994).

Fig. 4C shows the distribution of the tagged proteins with internal deletions in differentiated PC12 cells. When the large deletion covered the charged domain, the transmembrane domain, and the adjacent fragment of the intravesicular domain (construct $332 \Delta 90(49-138)$ ), the protein lost its ability to accumulate at the neurite terminals (a). The same pattern was revealed, when deletion was restricted by the borders of the transmembrane and the charged domains (construct 347 75 (64-138); data not shown). The deleted region includes conserved cysteine residues C90, C91, and C92 in the domain III, which have been reported to undergo palmitoylation (Chapman et al., 1996). Palmitoylation of proteins may be important for intracellular trafficking (Rothman, 1994). However, removal of these residues (construct 418 4 (89-92)) did not prevent transport of the protein to the terminals (d). Moreover, removal of the entire domain III (construct 372 $\Delta 50(89-138)$ ) also did not affect targeting (e). At the same time, when domain III was intact, but the transmembrane domain was removed (constructs 398424(64-87) and $383 \Delta 39(49-87)$ ), the proteins did not accumulate at the terminals ( $b$ and $c$ ). When the entire $\mathrm{C} 2 \mathrm{~A}$ and $\mathrm{C} 2 \mathrm{~B}$ domains (IV-VI), which constitute two-thirds of the synaptotagmin molecule, were removed (construct 184 $238(145-382)$ ), the recombinant protein was still able to accumulate at the terminals (f), indicating that these domains are not essential for targeting. Thus, protein comprised of amino-terminal (domains I, II, and III) and carboxy-terminal (domain VII) regions of the synaptotagmin molecule can be correctly transported to the terminals, suggesting that these regions are sufficient for targeting. 
Fine mapping of the carboxyterminal region

Our data suggest that structural elements in the carboxy-terminal domain may determine the accumulation of the synaptotagmin molecule at neurite terminals. We performed fine mapping of the carboxy-terminal region using short deletions and alanine scanning point mutagenesis. As follows from immunoblotting analysis, all proteins carrying deletions and point mutations were expressed at similar levels in transfected cells and produced bands of expected mobility (Figs 5A, 6A). When mutants lacking 3, 6, and 12 amino acids from the synaptotagmin carboxy terminus (constructs $419 \Delta 3$, $416 \Delta 6$, and $410 \Delta 12$ ) were tested by immunochemistry (Fig. 5B,a,b,c), their distribution was the same as that of the full-length wild-type Syt-HA (422 wt). However, when an additional 9 (construct $401 \Delta 21$ ) or more amino acids were removed proteins lost their preferential accumulation at the terminals and varicosities (d,e, and data not shown). These results demonstrate that the last 12 amino
A
$422 w t$

332 -90(49-138)

$347 \Delta 75(64-138)$

$398 \Delta 24(64-87)$

$383 \Delta 39(49-87)$

$418 \Delta 4(89-92)$

$372 \Delta 50(89-138)$

$184 \Delta 238(145-382)$

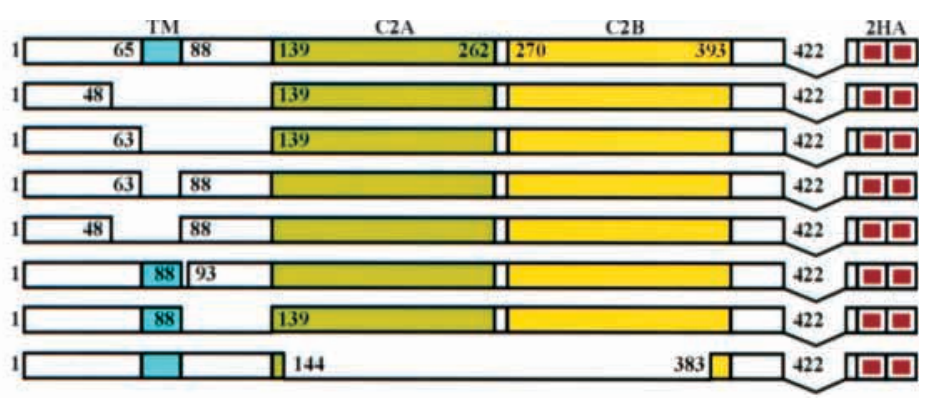

B
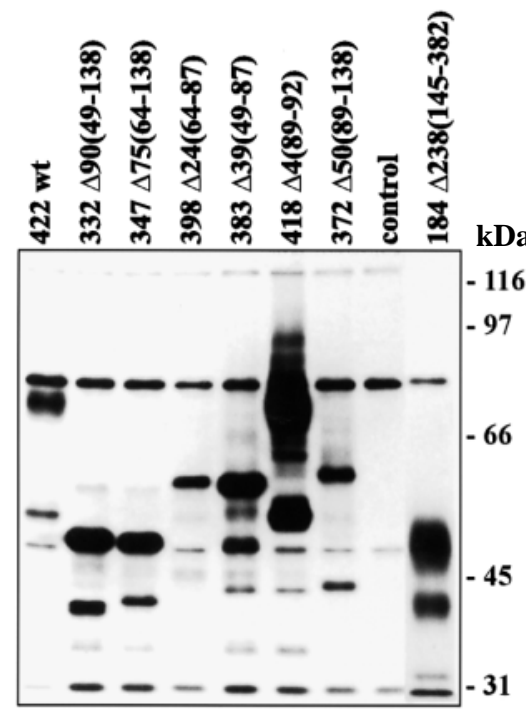

Fig. 4. Synaptotagmin mutants with internal deletions: expression and intracellular localization in PC12 cells. (A) Schematic representation of Syt-HA subclones with internal deletions of the transmembrane, charged (domains II, III), and $\mathrm{C} 2$ regions (domains IV-VI). (B) Expression of Syt-HA subclones with internal deletions. SDS-PAGE immunoblotting of whole cell SDS-lysates of transfected and control non-differentiated PC12 cells; anti-HA mAb. An equal amount of total protein was loaded $(10 \mu \mathrm{g} / \mathrm{lane}) ; 8.5 \%$ PAGE. (C,a-f) Immunofluorescence staining of NGFdifferentiated PC12 cells transfected with SytHA subclones bearing internal deletions and labeled with anti-HA mAb. In each case, similar images were captured from over 25 other cells in at least 3 independent experiments. Bar, $25 \mu \mathrm{m}$.
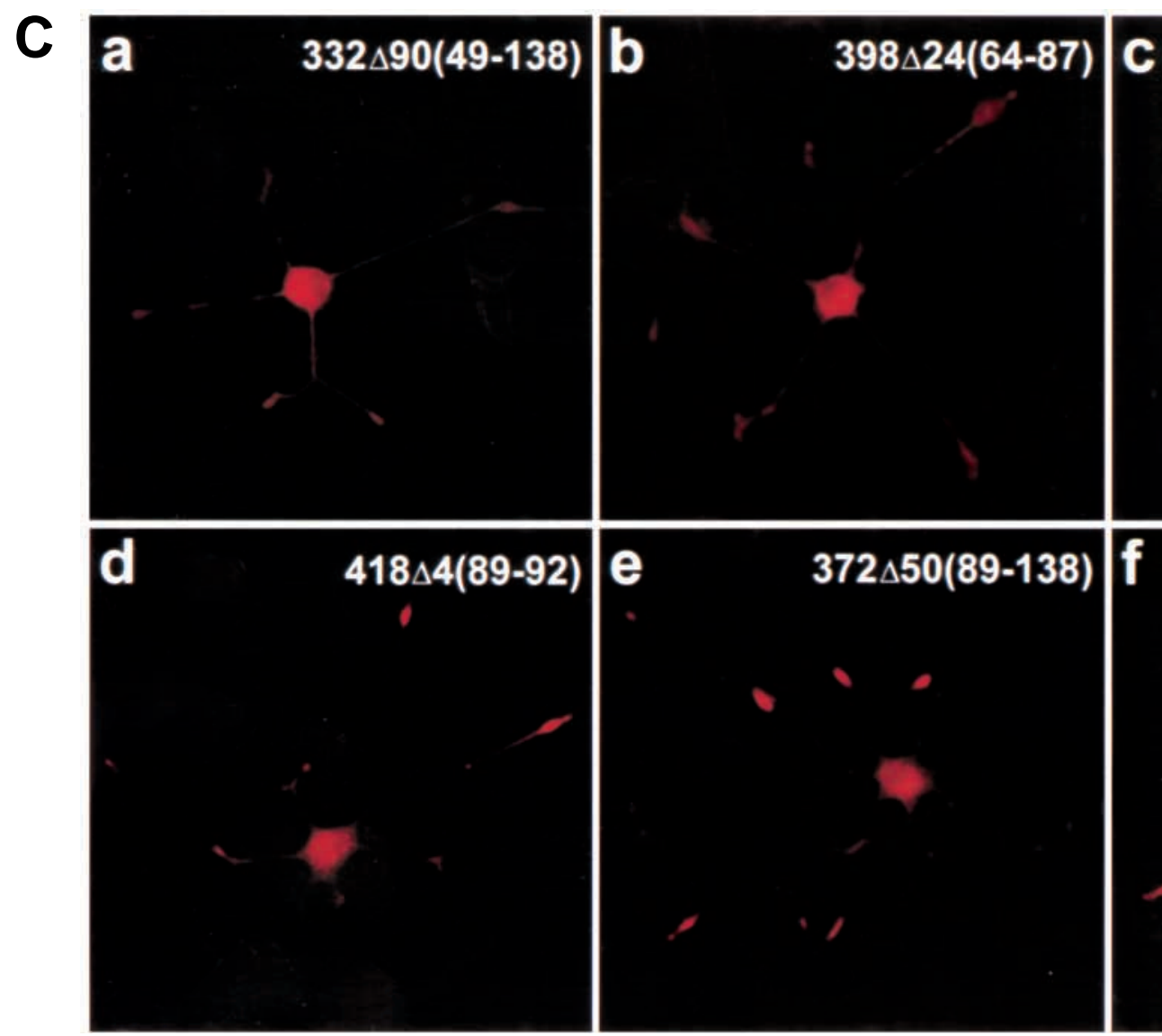

$383 \Delta 39(49-87)$
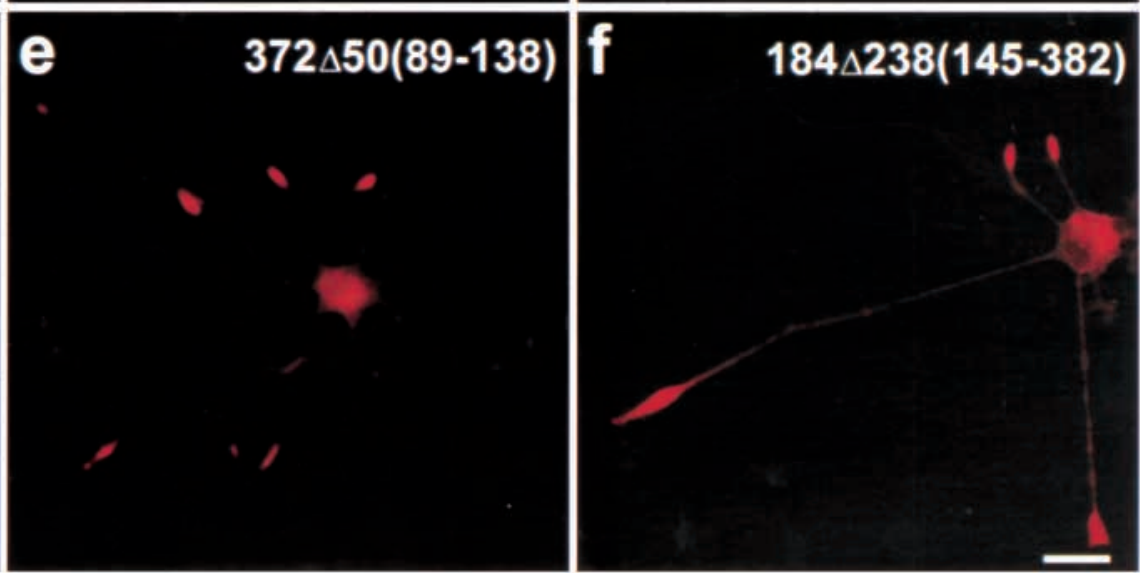
A

VGS NAT GTELRHW S M LANPRRPIA QW HSLKPEEEV D A L GK N K

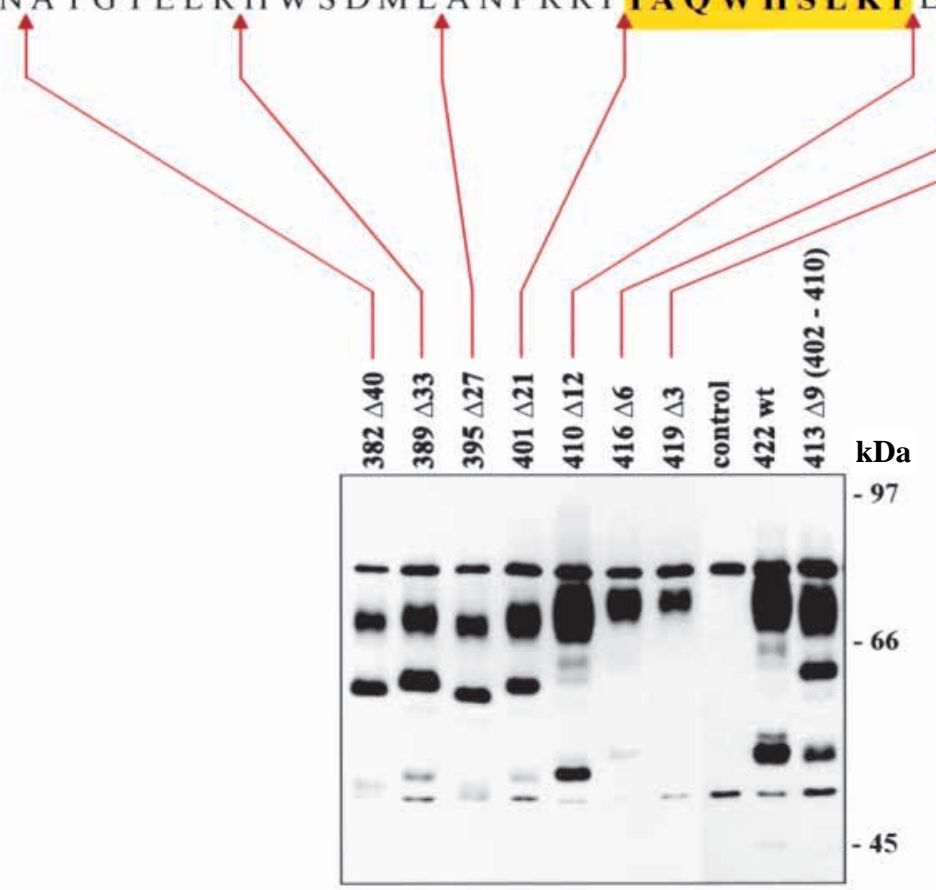

Fig. 5. Fine mapping of the carboxy-terminal targeting signal. (A) Schematic representation and immunoblotting analysis of expression in PC12 cells of Syt-HA subclones with small truncations of synaptotagmin carboxy terminus $(\Delta 3-\Delta 40$ amino acids) and of the variant with internal deletion 413 $\Delta 9$ (402-410). Equal amounts of total protein from whole cell SDS-lysates of transfected nondifferentiated PC12 cells was loaded (10 $\mu \mathrm{g} / \mathrm{lane}) ; 8.0 \%$ PAGE; anti-HA mAb. (B,a-f) Immunofluorescence staining of NGF-differentiated PC12 cells transfected with Syt-HA subclones indicated above and labeled with anti$\mathrm{HA}$ mAb. In each case, similar images were captured from over 25 other cells in at least 3 independent experiments. Bar, $25 \mu \mathrm{m}$.

B
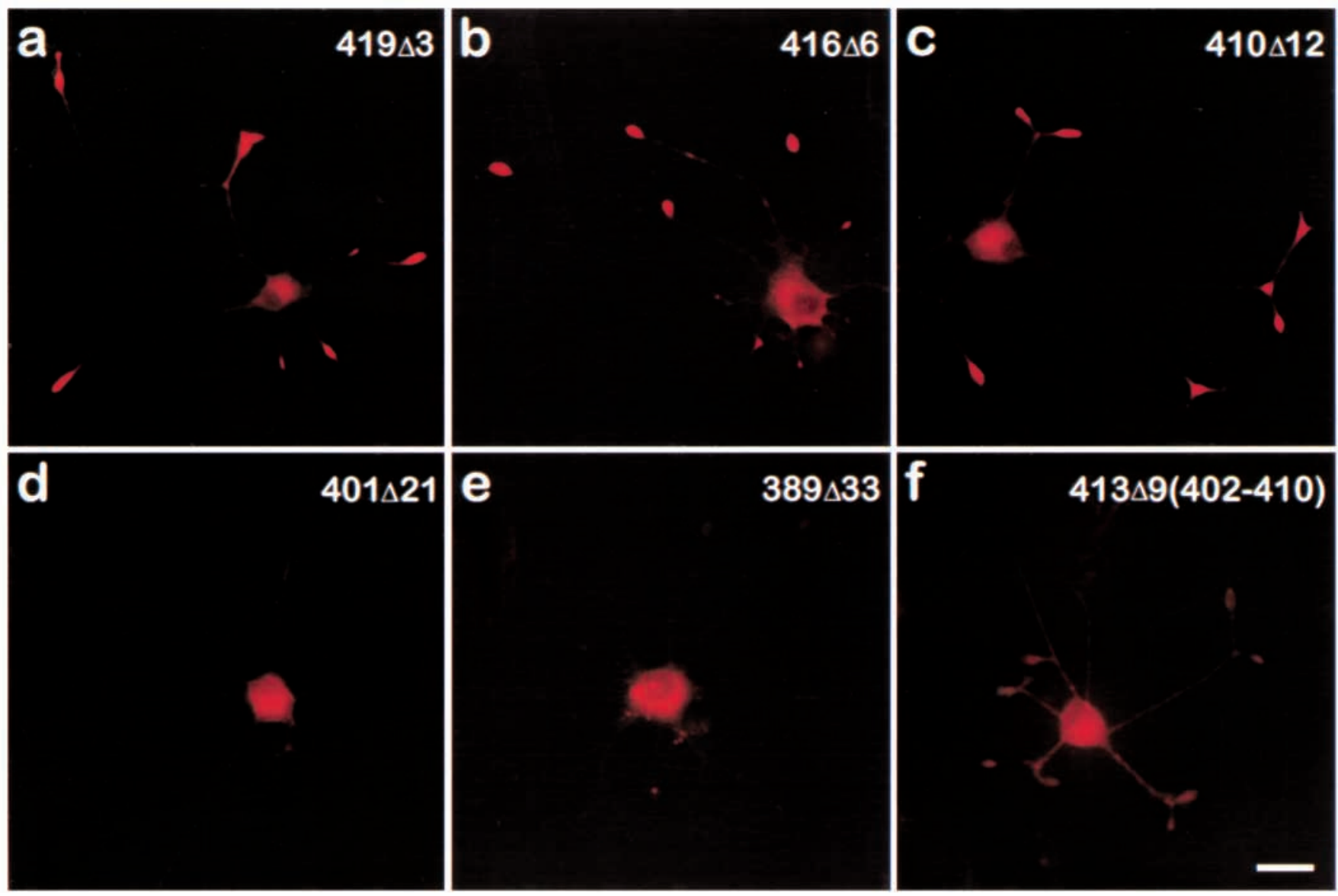
acids of synaptotagmin II are dispensable, whereas the region between amino acids 401 and 411 is necessary for the correct targeting of the molecule to the terminal. When this short stretch of amino acids was removed by an internal deletion (construct 413 $\Delta 9$ (402-410)), the molecules did not accumulate at the neurite terminals (f), supporting the notion that this sequence (IAQWHSLKP) contains amino acids critical for the targeting of synaptotagmin II to the terminals and may represent a targeting signal.

Interestingly, expression of mutants that failed to accumulate at the terminals (truncations $\Delta 21-\Delta 40$ and internal deletion $\Delta 9$ ), but not expression of other mutants $(\Delta 3-\Delta 12)$ or the wild type, was accompanied by the appearance of fragments with mobility 62-63 kDa (Fig. 5A), which likely arise from cleavage in the proteolytic site(s) located in the domain I. The same fragments were evident when cells were pretreated with $20 \%$ TCA to diminish possible protein degradation during preparation of whole cell lysates (data not shown) indicating that cleavage may occur in vivo. This suggests that certain mutations in the synaptotagmin carboxy terminus are able to modify the sensitivity of the proteolytic site(s) in its amino terminus. Appearance of these fragments may reflect increased accessibility for the degradation of some mutant molecules that are not able to reach their proper destinations at the terminals. However, the presence of the proteolytic fragments cannot greatly affect the results of the immunochemistry analysis because the major immunoreactivity is represented by uncleaved molecules.

To identify the critical amino acid residues within the carboxy-terminal targeting signal, we performed alanine scanning point mutagenesis of the IAQWHSLKP region, leaving the remaining portion of the Syt-HA protein intact. When the panel of point mutants was tested by immunochemistry (Fig. 6B), all but two of the constructs displayed enrichment at the tips of neurites similar to the wild type. In contrast, when tryptophan at position 405 (W405) or leucine at position 408 (L408) were changed to alanine, the proteins failed to accumulate at the neurite terminals (mutation of histidine at position 406 also impaired accumulation at the terminals but did not abolish it). Moreover, like other mutants that failed to accumulate at the terminals (Fig. 5A), W(405)A and L(408)A mutants, but not other constructs with point mutations in this region, were found to display the presence of the minor bands $(\sim 62-63 \mathrm{kDa})$ when tested by immunoblotting (Fig. 6A).

Thus, we conclude that W405 and L408 are indispensable for the proper targeting of synaptotagmin II to the neurite terminals. These two residues are absolutely conserved in all known synaptotagmin isoforms (see below), further supporting their crucial role as targeting determinants.

\section{DISCUSSION}

We have identified the structural elements of the molecule of the synaptic vesicle protein synaptotagmin II that are required for its targeting to the neurite terminals. Synaptotagmin accumulation at the neurite terminals is dependent on the carboxy-terminal domain (VII) of the protein, provided that the region of the transmembrane domain (II) is intact. Disruption of each of these elements prevents the correct distribution of the protein, whereas the deletion of the remaining part of the molecule (domains III, IV, V, and VI) has no effect.

The importance of the transmembrane region suggests that synaptotagmin must be incorporated into proper membrane organelles in order to utilize vesicular transport machinery via its carboxy-terminal domain. Interestingly, synaptic targeting of the peripheral synaptic vesicle protein rabphilin-3A, which lacks a transmembrane domain but shares extensive sequence similarity with the carboxy-terminal domain of synaptotagmin, is also dependent on association with a vesicle (via its interaction with an obligatory constituents of synaptic vesicles Rab3A and Rab3C) (Lin et. al., 1994).

Within the carboxy-terminal domain of the synaptotagmin molecule, we have identified a short stretch of amino acids (IAQWHSLKP) that is critical for targeting and have shown that two particular amino acids (W405 and L408) are indispensable for this function. Converting either one of these amino acids to alanine in the otherwise intact 422-residue protein prevents the accumulation of the entire synaptotagmin II molecule at the neurite terminals. This indicates that residues W405 and L408 (and to a lesser degree H406) may be crucial points of contact between the synaptotagmin molecule and the cell components that determine its itinerary in the neuronal cell. Noteworthy, when possible conformations of the synaptotagmin II carboxy-terminal domain were modeled using the Macromodel program (P. Nestler and P. Krasnov, unpublished), these crucial residues fell within the loop of a highly stable hairpin formed by the adjacent acidic and basic residues.

The notion that the carboxy-terminal domain of the synaptotagmin molecule contains a structural element that may determine protein accumulation at the terminals is further supported by the analysis of the evolutionary conservation of this region. Table 1 represents the alignment of carboxyterminal regions of all known synaptotagmin family members and synaptotagmin-related proteins from evolutionarily diverse species. It shows that carboxy terminus endings are not conserved and vary greatly in length and sequence, although the same isoforms of different species are more similar than different isoforms of the same species. This agrees well with our finding that the last 12 amino acids of the synaptotagmin II carboxy terminus are not necessary for its targeting functions. In contrast, the beginning and the middle parts of the carboxy-terminal domain reveal a remarkable degree of conservation. Within this conserved region, the sequence WHXL is invariable in all tested species throughout the entire synaptotagmin family and in synaptotagmin-related proteins (the only found exception was rat synaptotagmin isoform $\mathrm{Srg} 1$ where leucine is conservatively replaced by valine). The fact that the residues indispensable for targeting to the terminals are entirely conserved in this protein group across species suggests that the WHXL motif may serve as an actual targeting signal.

In many transmembrane proteins, short cytoplasmic amino acids motifs serve as sorting or targeting signals, which determine specific itinerary of the protein in the cell (Trowbridge et al., 1993; Rothman and Wieland, 1996). However, for the obligatory components of synaptic vesicles or secretory granules in neuronal cells, the data on the sorting or targeting signals are limited. It has been reported that the cytoplasmic domain of synaptophysin is necessary for the endocytosis of this protein (Linstedt and Kelly, 1991). Various 


\section{A}

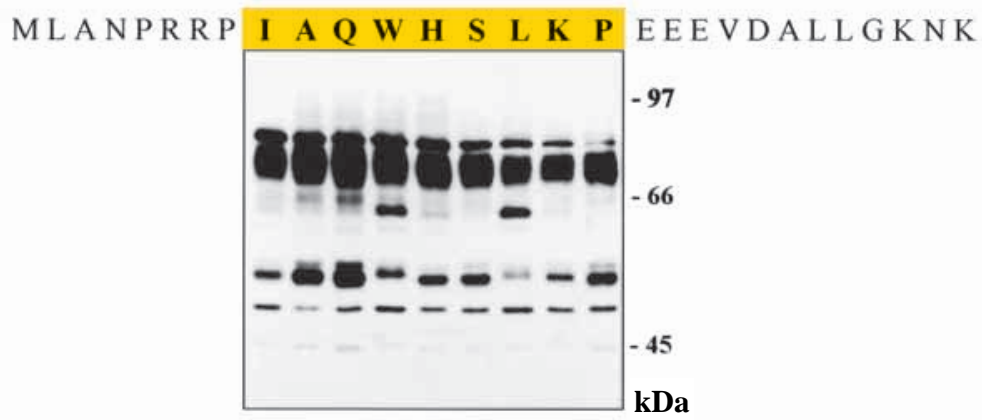

Fig. 6. Alanine scanning point mutagenesis of Syt-HA synaptotagmin carboxy terminus. (A) Schematic representation and immunoblotting analysis of expression in PC12 cells of Syt-HA subclones with point mutations in the IAQWHSLKP (402-410) region. Equal amount of total protein from whole cell SDS-lysates of transfected nondifferentiated PC12 cells was loaded $(10 \mu \mathrm{g} / \mathrm{lane}) ; 8.5 \%$ PAGE; anti-HA mAb. (B,a-h) Immunofluorescence staining of NGF-differentiated PC12 cells transfected with point mutants of Syt-HA and labeled with anti-HA mAb. In each case, similar images were captured from over 25 other cells in at least 3 independent experiments. Bar, $25 \mu \mathrm{m}$.

B
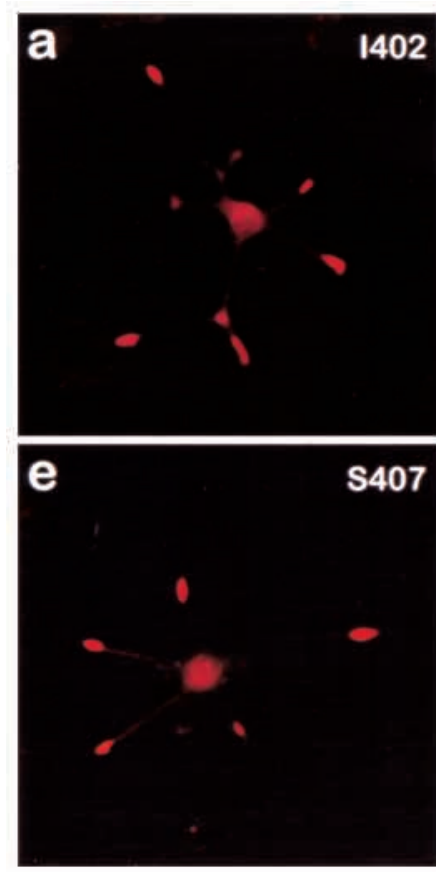
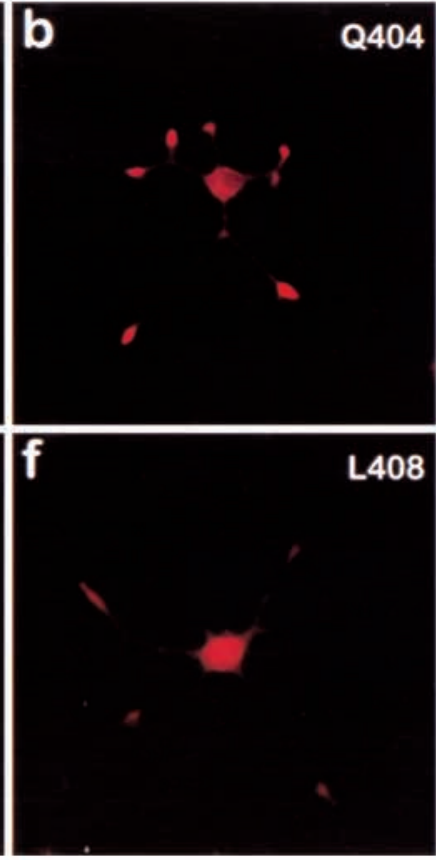
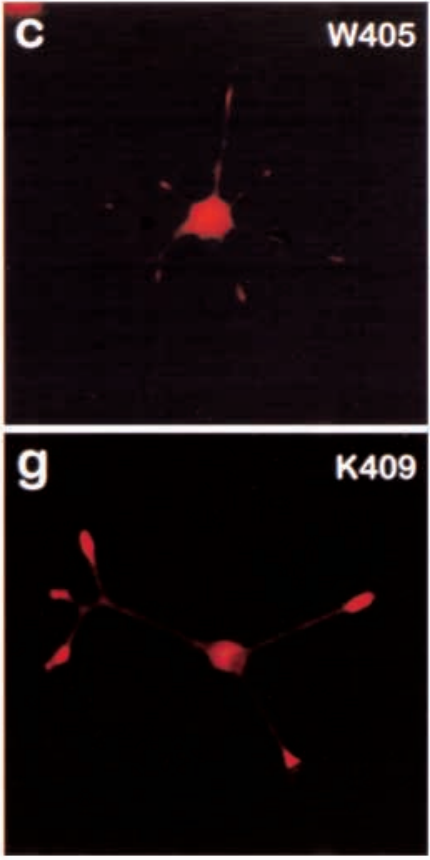
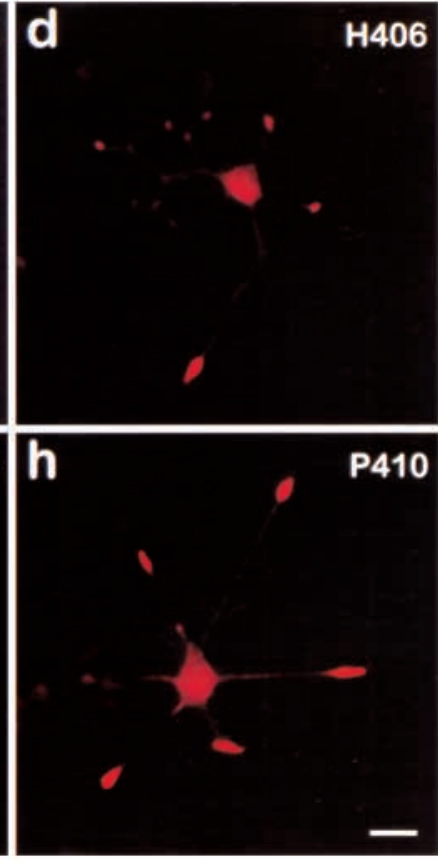

motifs have been shown necessary for endocytosis and/or sorting to synaptic vesicles or secretory granules of VAChT and VMAT (acetylcholine and monoamine transporters, respectively; Tan et al., 1998; Varoqui and Erickson, 1998), PAM (peptidyl-amidating monooxygenase; Milgram et al., 1996) and VAMP (vesicle-associated membrane protein or synaptobrevin; Grote et al., 1995; Grote and Kelly, 1996). Furthermore, cytoplasmic domain of VAMP fused to transferrin receptor was sufficient to target chimeric protein to the axons of cultured hippocampal neurons, although the axontargeting determinants of VAMP cannot be localized within any short amino acid motif, but are rather distributed along the cytoplasmic region (West et al., 1997).

There are several possible steps in the itinerary of synaptic vesicle proteins where the difference between the wild-type and mutant forms of synaptotagmin may determine whether the molecule will accumulate at the terminal. For instance, it is possible that the signal at the carboxy-terminal domain determines initial sorting of the protein and its incorporation into the correct membrane structures. The mutant forms may then become incorporated in the organelles that are not destined to be delivered to the neurite terminals. However, our data indicate that the distribution of the full-length form of SytHA, which is correctly targeted to the terminal, and of the truncated variant lacking 103 amino acids, which does not target correctly in a sucrose density gradient is similar. This suggests that both forms may be sorted to the same precursor organelles or vesicles and that the differences in their final distribution may be due to later events.

It is also possible that accumulation of synaptotagmin at the neurite terminals (and the failure of the mutant to do so) is due to the retention of the protein or the entire precursor organelle at the terminal. Such retention may be required before the protein, which is delivered to the terminal in association with a precursor organelle by fast anterograde transport, can be incorporated into mature synaptic vesicles. This step may be coupled with the discharge of the synaptotagmin-containing cargo organelle from the anterograde transport system once this organelle is delivered to the terminal by the motor proteins. Depending on the kinetics of these steps, the retaining molecule(s) at the nerve terminal need not necessarily be in stoichiometric proportion to the synaptotagmin molecules and 
Table 1. Carboxy-terminal sequences of species-specific synaptotagmin isoforms and related proteins

\begin{tabular}{|c|c|c|}
\hline Sytl, rat & YNSTGAELRHWSDILANPRRPIAQWHTLQVEEEVDAMLAVKK & X52772 \\
\hline SytII, rat & SNATGTELRHWSDMLANPRRPIAQWHSLKPEEEVDALLGKNK & M64488 \\
\hline SytIII, rat & EAADPHGREHWAEMLANPRKPVEHWHQLVEEKTLSSFTKGGKGLSEKENSE & D28512 \\
\hline SytiV, rat & ATAEGSGGGHWKE I CDFPRRQIAKWHMLCDG & U14398 \\
\hline SytV, rat & NEAERLGRDHWSEML SYPRKPIAHWHSLIEKR & U20108 \\
\hline SytVI, rat & I SAEGLGRDHWNEMLAYPRKPIAHWHCLAEVKKSFKEGTPRL & U20105 \\
\hline SytVII, rat & WKSGPGEVKHWKDMIARPRQPVAQWHQLKA & U20106 \\
\hline SytLX, rat & TAVGGAGLRHWADMLANPRRPIAQWHSLRPPDRARPIPAP & U26402 \\
\hline SytX, rat & LDAEGLGRDHWNEMLAYHRKP I THWHPL & U85513 \\
\hline SytXI, rat & HSVTTSGAEHWREVCE SPRKPVAKWHSLSEY & AF000423 \\
\hline Srg1, rat & PGASGMGTTHWNQMLATLRRPVSMWHPVRRN & U71294 \\
\hline Sytl, mouse & YNSTGAELRHWSDMLANPRRPIAQWHTLQVEEEVDAMLAVKK & D37792 \\
\hline SytII, mouse & SNATGTELRHWSDMLANPRRPIAQWHSLKPEEEVDALLGKNK & D37793 \\
\hline SytIII, mouse & EAADPHGREHWAEMLAN PRKPVEHWHQLVEEKTLSSFTKGGKGLSEKENSE & D45858 \\
\hline SytIV, mouse & ATAEGSGGGHWKE ICDFPRRQIAKWHMLCDG & U10355 \\
\hline SytVIII, mouse & SRASGQPLQHWADMLAHARRPIAQWHHLRSPREVDRVLALQPRLPLLRPRS & U20107 \\
\hline SytI, human & YNSTGAELRHWSDMLANPRRPIAQWHTLQVEEEVDAMLAVKK & M55047 \\
\hline SytiV, human & HSVTASGAEHWREVCESPRKPVAKWHSISEY & D38522 \\
\hline SytVII, human & WKSGPGEVXHWKDMIARPRQPVAQWHQLKA & AF038535 \\
\hline SytLX, human & AAAGGAGLRHWADMLANPRR PIAQWHSLRPPDRVRLLPAP & X96783 \\
\hline Syt1, bovine & YNSTGAELRHWSDMLANPRR P AQWHTLQVEEEVDAMLAVKK & A45486 \\
\hline Sytl, chicken & YNSTGAELRHWSDMLANPRRPIAQWHTLQPEEEVDAMLAVKK & S64957 \\
\hline Syt A, electric ray & N-STAAELRHWSDMLANPRRPIAQWHTLQPEEEVDATLGMKK & JH0413 \\
\hline Syt B, electric ray & NAS-GTELRHWSDMLANPRRPIAQWHSLKPEEEVDVALGLKK & M64276 \\
\hline Syt C, electric ray & NATDGPGREHWNEMLANPRKPIEQWHQLIEEKVMNSYMTKSFAAGTGATKPVTIVVESPHSV & M64277 \\
\hline Syt, Drosophila & CMGTGTELRHWSDMLASPRRPIAQWHTLKDPEETDEILKNMK & M55048 \\
\hline Syt, longfin squid & CNSTGTGLRHWSDMLANPRRPVAQWHTLQEVPEKN & D63797 \\
\hline Syt, sea hare & CNSSGTELRHWSDMLANPRRPIAQWHTLQEVPEKN & ve3125 \\
\hline Sytl, C. elegans & CNGTGAELRHWMDMLASPRRPIAQWHTLGPVEEEGDKKDDKK & U55856 \\
\hline Syt, C. elegans & PQITHACSEQWAEMMTS-RRPVVQWHTLQERMEKEKKKDDD & vo0es1 \\
\hline Rabphilin-3A, rat & I SAKGERLKHWYECLKNKDKKIERWHQLQNENHVSSD & U12571 \\
\hline Rabphilin-3A, mouse & I SAKGERLKHWYECLKNKDKKIERWHQLQNENHVSSD & JX0338 \\
\hline Rabphilin-3A, bovine & I SAKGERLKHWYECLKNKDKKIERWHQLQNENHVSSD & A48097 \\
\hline F37A4, C. elegans & TSAKDERGRQWIKCIENPGTLVEAWHRLELDS & P41885 \\
\hline Doc2A, rat & PGARGEAQKHWRDCLHQPDTAVERWHTLTSELPPAAGALPLA & U70779 \\
\hline Doc2B, rat & INAKGERLKHWFDCLKNKDKR IERWHTLTNELPGAVLSD & U70778 \\
\hline Doc2, mouse & PGARGEAQKHWNDCLHQPDTALERWHTLTSELPPAAGAYPLA & D50000 \\
\hline Doc2 beta, mouse & INAKGERLKHWFDCLNNKDKR IERWHTLTNELPGAVLSD & JC4921 \\
\hline Doc2, human & PGARGEARKHWSDCLQQRDAALERWHTLTSELPPAAGALSSA & JC2473 \\
\hline Doc2 beta, human & IHAKGERLKHWFDCLKNKDKR IERWHTLTSELPGAVLSD & D70830 \\
\hline $\mathrm{B} / \mathbf{K}$, rat & YS SGPSE SNHWRRMLNTHRTAVEQWHSLR SRAE CDRVSPASIEVT & U30831 \\
\hline B/K, human & YS SGPSETNHWRRMLNTHRTAVEQWHSLRSRAECDRVSPASLEVT & ACv03003 \\
\hline
\end{tabular}

Alignment was performed using GCG PileUp. On the right, sequences accession numbers (NCBI). Conserved elements of mirror symmetry motifs (Perin, 1996) are highlighted. Tryptophan and leucine residues, which are critical for synaptotagmin II targeting, are in red. Proteins are named in accordance with established nomenclature (Südhof and Rizo, 1996; Schiavo et al., 1998). Originally named rat and human synaptotagmins V (Craxton and Goedert, 1995; Hudson and Birnbaum, 1995; Craxton et al., 1997) are referred to as synaptotagmins IX. The group of synaptotagmin-related proteins is represented by rabphilin-3A, doc2 isoforms and B/K protein; according to BLAST analysis, hypothetical protein F37A4.7 is likely C. elegans specific isoform of rabphilin-3A. All these proteins share sequence similarity with synaptotagmin and possess synaptotagmin-like domain structure, but lack a transmembrane-spanning domain. Rabphilin3A (Li et al., 1994) and closely related doc2 isoforms (Orita et al., 1995) are associated with peripheral membrane proteins of synaptic vesicles; membrane anchoring is also suggested for B/K protein (Kwon et al., 1996).

may be represented by a small number of protein molecules. To date, synaptotagmin is known to interact with a number of proteins. However, most of them, such as the components of the multimeric synaptic docking and fusion complex syntaxin (Chapman et al., 1995; Kee and Scheller, 1996), SNAP-25 and $\beta$-SNAP (Schiavo et al., 1995, 1997), as well as SV2 (Schivell et al., 1996), N-type and P/Q-type calcium channels (Sheng et al., 1997; Charvin et al., 1997), and clathrin adaptor AP-2 (Zhang et al., 1994) bind to synaptotagmin via its C2A or C2B domains. Synaptotagmin is also known to interact with calmodulin (Trifaro et al., 1989). However, the calmodulin binding site is located in the very beginning of the synaptotagmin carboxy terminus sequence, and the WHXL motif does not participate in this interaction (Perin et al., 1996). Other proteins known to interact with synaptotagmin are neurexins. They constitute a large polymorphic family of low abundance plasma membrane proteins with the characteristics of cell surface receptors. Neurexins are expressed in neuronal 
and neuroendocrine cells and enriched at the nerve terminals (Valtorta et al., 1984; Ushkaryov et al., 1992; Ullrich et al., 1995). The precise biological function of neurexins is unclear; however, they may be involved in synaptic neuron-neuron interactions, and in the regulation of docking and neurotransmitter release (Missler et al., 1998). Neurexins have been reported to interact in vitro with various synaptotagmin isoforms and also with synaptotagmin-related protein rabphilin-3A (Surkova and Grishin, 1991; Petrenko et al., 1991; Hata et al., 1993; Perin, 1994, 1996). Importantly, these interactions occur via the carboxy-terminal domains of synaptotagmin and rabphilin-3A (Perin, 1994, 1996). Moreover, peptide-binding studies have demonstrated that the crucial points of contact with neurexins in the synaptotagmin and rabphilin-3A carboxytermini include the conserved WHXL motif and its mirror image symmetry counterpart, which resides at the beginning of the carboxy terminus sequence (Perin, 1996; Table 1). Therefore, there is a remarkable correlation between synaptotagmin residues that are important for synaptotagmin-neurexin interaction and those that were identified in our experiments as critical for targeting. Thus, a plausible explanation for the targeting features of the carboxy-terminal signal involves synaptotagmin-neurexin interactions. It is possible that neurexin binds to synaptotagmin-containing vesicles and facilitates their initial retention, hence contributing to their eventual accumulation at the terminals.

Finally, it is possible that the carboxy-terminal targeting signal determines the interactions of the synaptotagmin molecule with the motor proteins involved in the fast anterograde transport of the vesicles to the terminals, and that mutations in the targeting signal compromise this binding. Members of the recently identified kinesin superfamily appear to be involved in the fast anterograde transport of different organelles (Goodson et al., 1997; Hirokawa, 1998). Some of them are neuronal specific and implicated in delivery to the nerve terminal of precursor organelles loaded with different components of plasma membrane and synaptic vesicles including synaptotagmin (Okada et al., 1995; Amaratunga et al., 1995; Hurd and Saxton, 1996). Importantly, these different components are likely to be presorted before delivery and are probably transported to the terminals as components of different precursor vesicles. For instance, the presence of at least two different types of transported precursor organelles carrying different sets of proteins and employing different motors has been shown (Okada et al., 1995). One type contained synaptotagmin, synaptophysin, and Rab3A and was associated with motor protein KIF1A, whereas another contained SV2 and plasma membrane components (syntaxin 1 and SNAP-25) and was not associated with KIF1A. Moreover, a sciatic nerve ligation experiment demonstrated abolition of synaptotagmin, but not syntaxin 1, transport in KIF1Adeficient mice (Yonekawa et al., 1998). Thus, it is conceivable that mutations in the synaptotagmin carboxy terminus, which prevent the delivery of the protein to the terminals, may act by disrupting the interactions of synaptotagmin with a specific kinesin-type motor molecule.

We thank Thomas Südhof and Reinhard Jahn for the gifts of the synaptotagmin II gene and anti-synaptotagmin antibodies. We are grateful to our summer students (CSHL Undergraduate Research
Program) Jonathan Chubb and Nathan Hellman for the productive work and discussions. We are grateful to Jacek Skowronski, Roberto Malinow, and Alexander Petrenko for critical reading of the manuscript. We are grateful to Gregory Bannikov, Anatoly Gleiberman, Alex Strongin, and Irene Miloslavskaya for advice. We thank Catriona Simpson, Santosh John, and Barbara Mish for the help with manuscript preparation. We thank all the members of Enikolopov laboratory for contributive discussions. This work was supported by grants from NIH and Klingenstein Foundation to G.E. and from Wendt Foundation to P.K.

\section{REFERENCES}

Amaratunga, A., Leeman, S. E., Kosik, K. S. and Fine, R. E. (1995). Inhibition of kinesin synthesis in vivo inhibits the rapid transport of representative proteins for three transport vesicle classes into the axon. $J$. Neurochem. 64, 2374-2376.

Bauerfeind, R., Regnier-Vigouroux, A., Flatmark, T. and Huttner, W. B. (1993). Selective storage of acetylcholine, but not catecholamines, in neuroendocrine synaptic-like microvesicles of early endosomal origin. Neuron 11, 105-121.

Bonzelius, F., Herman, G. A., Cardone, M. H., Mostov, K. E. and Kelly, R. B. (1994). The polymeric immunoglobulin receptor accumulates in specialized endosomes but not synaptic vesicles within the neurites of transfected neuroendocrine PC12 cells. J. Cell. Biol. 127, 1603-1616.

Brose, N., Petrenko, A. G., Südhof, T. C. and Jahn, R. (1992). Synaptotagmin: a calcium sensor on the synaptic vesicle surface. Science 256, 1021-1025.

Calakos, N. and Scheller, R. H. (1996). Synaptic vesicle biogenesis, docking, and fusion: a molecular description. Physiol. Rev. 76, 1-29.

Chapman, E. R., Hanson, P. I., An, S. and Jahn, R. (1995). $\mathrm{Ca}^{2+}$ regulates the interaction between synaptotagmin and syntaxin 1. J. Biol. Chem. 270, 23667-23671.

Chapman, E. R., Blasi, J., An, S., Brose, N., Johnston, P. A., Südhof, T. C. and Jahn, R. (1996). Fatty acylation of synaptotagmin in PC12 cells and synaptosomes. Biochem. Biophys. Res. Commun. 225, 326-332.

Charvin, N., L'eveque, C., Walker, D., Berton, F., Raymond, C., Kataoka, M., Shoji-Kasai, Y., Takahashi, M., De Waard, M. and Seagar, M. J. (1997). Direct interaction of the calcium sensor protein synaptotagmin I with a cytoplasmic domain of the alpha1A subunit of the P/Q-type calcium channel. EMBO J. 16, 4591-4596.

Clift-O'Grady, L., Linstedt, A. D., Lowe, A. W., Grote, E. and Kelly, R. B. (1990). Biogenesis of synaptic vesicle-like structures in a pheochromocytoma cell line PC-12. J. Cell Biol. 110, 1693-1703.

Craxton, M. and Goedert, M. (1995). Synaptotagmin V: a novel synaptotagmin isoform expressed in rat brain. FEBS Lett. 361, 196-200.

Craxton, M., Olsen, A. and Goedert, M. (1997). Human synaptotagmin V (SYT5): sequence, genomic structure, and chromosomal location. Genomics 42, 165-169.

Cutler, D. F. and Cramer, L. P. (1990). Sorting during transport to the surface of PC12 cells: divergence of synaptic vesicle and secretory granule proteins. J. Cell Biol. 110, 721-730.

De Camilli, P. and Takei, K. (1996). Molecular mechanisms in synaptic vesicle endocytosis and recycling. Neuron 16, 481-486.

Elferink, L. A., Peterson, M. R. and Scheller, R. H. (1993). A role for synaptotagmin (p65) in regulated exocytosis. Cell 72, 153-159.

Feany, M. B., Yee, A. G., Delvy, M. L. and Buckley, K. M. (1993). The synaptic vesicle proteins SV2, synaptotagmin and synaptophysin are sorted to separate cellular compartments in CHO fibroblasts. J. Cell Biol. 123, 575-584.

Field, J., Nikawa, J., Broek, D., MacDonald, B., Rodgers, L., Wilson, I. A., Lerner, R. A. and Wigler, M. (1988). Purification of a RAS-responsive adenylyl cyclase complex from Saccharomyces cerevisiae by use of an epitope addition method. Mol. Cell. Biol. 8, 2159-2165.

Geppert, M., Archer, B. T. III and Südhof, T. C. (1991). Synaptotagmin II. A novel differentially distributed form of synaptotagmin. J. Biol. Chem. 266, 13548-13552.

Geppert, M. and Südhof, T. C. (1998). RAB3 and synaptotagmin: the yin and yang of synaptic membrane fusion. Annu. Rev. Neurosci. 21, 75-95.

Goodson, H. V., Valetti, C. and Kreis, T. E. (1997). Motors and membrane traffic. Curr. Opin. Cell. Biol. 9, 18-28.

Greene, L. A., Aletta, J. M., Rukenstein, A. and Green, S. H. (1987). PC12 pheochromocytoma cells: culture, nerve growth factor treatment, and experimental exploitation. Meth. Enzymol. 147, 207-216. 
Grote, E., Hao, J. C., Bennett, M. K. and Kelly, R. B. (1995). A targeting signal in VAMP regulating transport to synaptic vesicles. Cell 81, 581-589.

Grote, E. and Kelly, R. B. (1996). Endocytosis of VAMP is facilitated by a synaptic vesicle targeting signal. J. Cell Biol. 132, 537-547.

Harlow, E. and Lane, D. (1988). Antibodies: A Laboratory Manual. Cold Spring Harbor, New York: Cold Spring Harbor Laboratory Press.

Hata, Y., Davletov, B., Petrenko, A. G., Jahn, R. and Südhof, T. C. (1993). Interaction of synaptotagmin with the cytoplasmic domains of neurexins. Neuron 10, 307-315.

Hirokawa, N. (1998). Kinesin and dynein superfamily proteins and the mechanism of organelle transport. Science 279, 519-526.

Hou, X. E., Li, J. Y. and Dahlström, A. (1997). Clathrin light chain and synaptotagmin I in rat sympathetic neurons. J. Auton. Nerv. Syst. 62, 13-26.

Hudson, A. W., Fingar, D. C., Seidner, G. A., Griffiths, G., Burke, B. and Birnbaum, M. J. (1993). Targeting of the 'insulin-responsive' glucose transporter (GLUT4) to the regulated secretory pathway in PC12 cells. $J$. Cell Biol. 122, 579-588.

Hudson, A. W. and Birnbaum, M. J. (1995). Identification of a nonneuronal isoform of synaptotagmin. Proc. Nat. Acad. Sci. USA 92, 5895-5899.

Hurd, D. D. and Saxton, W. M. (1996). Kinesin mutations cause motor neuron disease phenotypes by disrupting fast axonal transport in Drosophila. Genetics 144, 1075-1085.

Huttner, W. B., Ohashi, M., Kehlenbach, R. H., Barr, F. A., Bauerfeind, R., Braunling, O., Corbeil, D., Hannah, M., Pasolli, H. A., Schmidt, A., Schmidt, A. A., Thiele, C., Wang, Y., Kromer, A. and Gerdes, H. -H. (1995). Biogenesis of neurosecretory vesicles. Cold Spring Harb. Symp. Quant. Biol. 60, 315-327.

Kee, Y. and Scheller, R. H. (1996). Localization of synaptotagmin-binding domains on syntaxin. J. Neurosci. 16, 1975-1981.

Kelly, R. B. and Grote, E. (1993). Protein targeting in the neuron. Annu. Rev. Neurosci. 16, 95-127.

Kwon O. J., Gainer, H., Wray, S. and Chin, H. (1996). Identification of a novel protein containing two $\mathrm{C} 2$ domains selectively expressed in the rat brain and kidney. FEBS Lett. 378, 135-139.

Lah, J. J. and Burry, R. W. (1993). Neuronotypic differentiation results in reduced levels and altered distribution of synaptophysin in PC12 cells. $J$. Neurochem. 60, 503-512.

Li, C., Takei, K., Geppert, M., Daniell, L., Stenius, K., Chapman, E. R., Jahn, R., De Camilli, P. and Südhof, T. C. (1994). Synaptic targeting of rabphilin-3A, a synaptic vesicle $\mathrm{Ca}^{2+} /$ phospholipid-binding protein, depends on rab3A/3C. Neuron 13, 885-898.

Lin, H. C., Lei, S. P. and Wilcox, G. (1985). An improved DNA sequencing strategy. Anal. Biochem. 147, 14-19.

Linstedt, A. D. and Kelly, R. B. (1991). Endocytosis of the synaptic vesicle protein, synaptophysin, requires the $\mathrm{COOH}-$ terminal tail. J. Physiol. (Paris) 85, 90-96.

Maniatis, T., Fritsch, E. F. and Sambrook, J. (1989). Molecular Cloning: A Laboratory Manual. Second Edition. Cold Spring Harbor, New York: Cold Spring Harbor Laboratory Press.

Marxen, M., Maienschein, V., Volknandt, W. and Zimmermann, H. (1997). Immunocytochemical localization of synaptic proteins at vesicular organelles in PC12 cells. Neurochem. Res. 22, 941-950.

Matteoli, M., Takei, K., Cameron, R., Hurlbut, P., Johnston, P. A., Südhof, T. C., Jahn, R. and De Camilli, P. (1991). Association of Rab3A with synaptic vesicles at late stages of the secretory pathway. J. Cell Biol. 115, 625-633.

Matthew, W. D., Tsavaler, L. and Reichardt, L. F. (1981). Identification of a synaptic vesicle-specific membrane protein with a wide distribution in neuronal and neurosecretory tissue. J. Cell Biol. 91, 257-269.

Milgram, S. L., Mains, R. E. and Eipper, B. A. (1996). Identification of routing determinants in the cytosolic domain of a secretory granuleassociated integral membrane protein. J. Biol. Chem. 271, 1752617535.

Missler, M., Fernandez-Chacon, R. and Südhof, T. C. (1998). The making of neurexins. J. Neurochem. 71, 1339-1347.

Okada, Y., Yamazaki, H., Sekine-Aizawa, Y. and Hirokawa, N. (1995). The neuron-specific kinesin superfamily protein KIF1A is a unique monomeric motor for anterograde axonal transport of synaptic vesicle precursors. Cell 81, 769-780.

Orita, S., Sasaki, T., Naito, A., Komuro, R., Ohtsuka, T., Maeda, M., Suzuki, H., Igarashi, H. and Takai, Y. (1995). Doc2: a novel brain protein having two repeated C2-like domains. Biochem. Biophys. Res. Commun. 206, 439-448.

Perin, M. S., Fried, V. A., Mignery, G. A., Jahn, R. and Südhof, T. C.
(1990). Phospholipid binding by a synaptic vesicle protein homologous to the regulatory region of protein kinase C. Nature 345, 260-263.

Perin, M. S., Johnston, P. A., Ozcelik, T., Jahn, R., Francke, U. and Südhof, T. C. (1991a). Structural and functional conservation of synaptotagmin (p65) in Drosophila and humans. J. Biol. Chem. 266, 615-622.

Perin, M. S., Brose, N., Jahn, R. and Südhof, T. C. (1991b). Domain structure of synaptotagmin (p65). J. Biol. Chem. 266, 623-629.

Perin, M. S. (1994). The $\mathrm{COOH}$ terminus of synaptotagmin mediates interaction with the neurexins. J. Biol. Chem. 269, 8576-8581.

Perin, M. S. (1996). Mirror image motifs mediate the interaction of the $\mathrm{COOH}$ terminus of multiple synaptotagmins with the neurexins and calmodulin Biochem. 35, 13808-13816.

Petrenko, A. G., Perin, M. S., Davletov, B. A., Ushkaryov, Y. A., Geppert, M. and Südhof, T. C. (1991). Binding of synaptotagmin to the alphalatrotoxin receptor implicates both in synaptic vesicle exocytosis. Nature 353, 65-68.

Ramaswami, M., Krishnan, K. S. and Kelly, R. B. (1994). Intermediates in synaptic vesicle recycling revealed by optical imaging of Drosophila neuromuscular junctions. Neuron 13, 363-375.

Rothman, J. E. (1994). Mechanisms of intracellular protein transport. Nature 372, 55-63.

Rothman, J. E. and Wieland, F. T. (1996). Protein sorting by transport vesicles. Science 272, 227-234.

Schiavo, G., Gmachl, M. J., Stenbeck, G., Sollner, T. H. and Rothman, J. E. (1995). A possible docking and fusion particle for synaptic transmission. Nature 378, 733-736

Schiavo, G., Stenbeck, G., Rothman, J. E. and Sollner, T. H. (1997). Binding of the synaptic vesicle v-SNARE, synaptotagmin, to the plasma membrane t-SNARE, SNAP-25, can explain docked vesicles at neurotoxintreated synapses. Proc. Nat. Acad. Sci. USA 94, 997-1001.

Schiavo, G., Osborne, S. L. and Sgouros, J. G. (1998). Synaptotagmins: more isoforms than functions? Biochem. Biophys. Res. Commun. 248, 1-8.

Schivell, A. E., Batchelor, R. H. and Bajjalieh, S. M. (1996). Isoformspecific, calcium-regulated interaction of the synaptic vesicle proteins SV2 and synaptotagmin. J. Biol. Chem. 271, 27770-27775.

Schmidle, T., Weiler, R., Desnos, C., Scherman, D., Fischer-Colbrie, R., Floor, E. and Winkler, H. (1991). Synaptin/synaptophysin, p65 and SV2: their presence in adrenal chromaffin granules and sympathetic large dense core vesicles. Biochim. Biophys. Acta 1060, 251-256.

Sheng, Z. H., Yokoyama, C. T. and Catterall, W. A. (1997). Interaction of the synprint site of $\mathrm{N}$-type $\mathrm{Ca}^{2+}$ channels with the $\mathrm{C} 2 \mathrm{~B}$ domain of synaptotagmin I. Proc. Nat. Acad. Sci. USA 94, 5405-5410.

Spector, D. L., Goldman, R. D. and Leinwand, L. A. (1998). Cells: A Laboratory Manual. Cold Spring Harbor, New York: Cold Spring Harbor Laboratory Press.

Südhof, T. C. (1995). The synaptic vesicle cycle: a cascade of protein-protein interactions. Nature 375, 645-653.

Südhof, T. C. and Rizo, J. (1996). Synaptotagmins: C2-Domain proteins that regulate membrane traffic. Neuron 17, 379-388.

Surkova, I. N. and Grishin, E. V. (1991). Presynaptic alpha-latrotoxin receptor components interact with protein p65 of synaptic vesicle membranes. Biomed. Sci. 2, 417-420.

Tan, P. K., Waites, C., Liu, Y., Krantz, D. E. and Edwards R. H. (1998). A leucine-based motif mediates the endocytosis of vesicular monoamine and acetylcholine transporters. J. Biol. Chem. 273, 17351-17360.

Trifaro, J. -M., Fournier, S. and Novas, M. L. (1989). The p65 protein is a calmodulin-binding protein present in several types of secretory vesicles. Neuroscience 29, 1-8.

Trowbridge, I. S., Collawn, J. F. and Hopkins, C. R. (1993). Signaldependent membrane protein trafficking in the endocytic pathway. Аnпи. Rev. Cell Biol. 9, 129-161.

Tugal, H. B., van Leeuwen, F., Apps, D. K., Haywood, J. and Phillips J. H. (1991). Glycosylation and transmembrane topography of bovine chromaffin granule p65. Biochem. J. 279, 699-703.

Ullrich, B., Ushkaryov, Y. A. and Südhof, T. C. (1995). Cartography of neurexins: more than 1000 isoforms generated by alternative splicing and expressed in distinct subsets of neurons. Neuron 14, 497-507.

Ushkaryov, Y. A., Petrenko, A. G., Geppert, M. and Südhof, T. C. (1992). Neurexins: synaptic cell surface proteins related to the alpha-latrotoxin receptor and laminin. Science 257, 50-56.

Valtorta, F., Madeddu, L., Meldolesi, J. and Ceccarelli, B. (1984). Specific localization of the alpha-latrotoxin receptor in the nerve terminal plasma membrane. J. Cell Biol. 99, 124-132.

Varoqui, H. and Erickson, J. D. (1998). The cytoplasmic tail of the vesicular 
acetylcholine transporter contains a synaptic vesicle targeting signal. J. Biol. Chem. 273, 9094-9098.

Veit, M., Sollner, T. H. and Rothman, J. E. (1996). Multiple palmitoylation of synaptotagmin and the t-SNARE SNAP-25. FEBS Lett. 385, 119-123.

Walch-Solimena, C., Takei, K., Marek, K. L., Midyett, K., Südhof, T. C., De Camilli, P. and Jahn, R. (1993). Synaptotagmin: a membrane constituent of neuropeptide-containing large dense-core vesicles. $J$. Neurosci. 13, 3895-3903.

Walch-Solimena, C., Blasi, J., Edelmann, L., Chapman, E. R., von Mollard, G. F. and Jahn, R. (1995). The t-SNAREs syntaxin 1 and SNAP25 are present on organelles that participate in synaptic vesicle recycling. $J$. Cell Biol. 128, 637-645.

Wendland, B., Miller, K. G., Schilling, J. and Scheller, R. H. (1991). Differential expression of the p65 gene family. Neuron 6, 993-1007.
Wendland, B. and Scheller, R. H. (1994). Secretion in AtT-20 cells stably transfected with soluble synaptotagmins. Mol. Endocrinol. 8, 1070-1082.

West, A. E., Neve, R. L. and Buckley, K. M. (1997). Targeting of the synaptic vesicle protein synaptobrevin in the axon of cultured hippocampal neurons: evidence for two distinct sorting steps. J. Cell Biol. 139, 917-927.

Winkler, H. (1997). Membrane composition of adrenergic large and small dense cored vesicles and of synaptic vesicles: consequences for their biogenesis. Neurochem. Res. 22, 921-932.

Yonekawa, Y., Harada, A., Okada, Y., Funakoshi, T., Kanai, Y., Takei, Y., Terada, S., Noda, T. and Hirokawa, N. (1998). Defect in synaptic vesicle precursor transport and neuronal cell death in KIF1A motor protein-deficient mice. J. Cell Biol. 141, 431-441.

Zhang, J. Z., Davletov, B. A., Südhof, T. C. and Anderson, R. G. (1994). Synaptotagmin I is a high affinity receptor for clathrin AP-2: implications for membrane recycling. Cell 78, 751-760. 